Discussion Paper No. 03-20

Do Computers Call for Training? Firm-level Evidence on Complementarities Between ICT and Human Capital Investments

Thomas Hempell

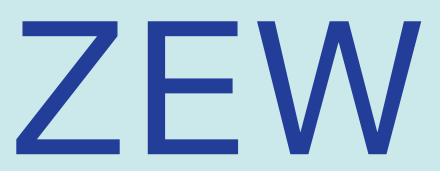

Zentrum für Europäische Wirtschaftsforschung GmbH

Centre for European Economic Research 
Discussion Paper No. 03-20

\title{
Do Computers Call for Training? Firm-level Evidence on Complementarities Between ICT and Human Capital Investments
}

\author{
Thomas Hempell
}

Download this ZEW Discussion Paper from our ftp server:

ftp://ftp.zew.de/pub/zew-docs/dp/dp0320.pdf

Das Papier entstand im Rahmen des Forschungsprojekts "Produktivitäts- und Spillovereffekte von IKT als General Purpose Technology" im Auftrag der Landesstiftung Baden-Württemberg.

The paper was written as part of the research project "Productivity and Spillover Effects of ICT as a Gerneral Purpose Technology" commissioned by the Landesstiftung Baden-Württemberg foundation.

Die Discussion Papers dienen einer möglichst schnellen Verbreitung von neueren Forschungsarbeiten des ZEW. Die Beiträge liegen in alleiniger Verantwortung der Autoren und stellen nicht notwendigerweise die Meinung des ZEW dar.

Discussion Papers are intended to make results of ZEW research promptly available to other economists in order to encourage discussion and suggestions for revisions. The authors are solely responsible for the contents which do not necessarily represent the opinion of the ZEW. 


\section{Non-technical summary}

Over the last decades, the continuously falling prices of information and communication technologies (ICT) have been spurring the demand for computers and networks. The successful implementation of ICT, however, is anything but trivial and requires various complementary strategies in order to pay off for firms. This paper explores the role of firm-sponsored training programmes for the productive usage of ICT.

Training is important since investments in ICT are often complemented by changes in the contents and the organisation of workplaces in firms. Computers and networks increasingly allow workers to share access to databases, to inter connect their workplaces and to co-ordinate business processes with suppliers and clients. On the other hand, rather standardised subtasks are increasingly done by computers. These changes in the composition of work tasks require a continuous updating of worker's skills. Many of these adjustments refer to firm-specific skills that are conveyed in training measures.

The empirical link between investments in ICT and training is explored for more than 1200 German firms in business-related and distribution services for the years 1994 to 1998. The study finds broad evidence that firms complement ICT investments by training programmes for their employees. Training and ICT investments are highly correlated even if varying firm characteristics like industry and size, among others, are taken into account.

Instead of reflecting productivity gains from synergies, the high correlation of ICT and training expenditures may be due to other factors, like particular rewarding schemes for employees or common trends in management practices. A more detailed analysis of productivity contributions invalidates such objections. The employed econometric approach controls for various interfering factors that may bias the assessment of productivity contributions. Moreover, the analysis explicitly takes into account potential time lags between the time of investments and the resulting productivity effects.

The results from the productivity analysis show that firms that invest strongly in both training and ICT perform significantly better than competitors that pursue rather isolated investment strategies. An important prerequisite for this combined investment to work, however, is a high share of well-educated employees in the workforce. Obviously, the educational level not only contributes directly to firm productivity but also forms a key factor for the effectiveness of training.

Finally, the paper assesses whether the productivity improvements due to training are offset by increases in the wage costs. This would diminish firms' incentives to invest in training measures. The results show that such training disincentives exist, but are mitigated by ICT investments: the share of productivity gains that can be appropriated by the investing firm is higher in firms with sizeable ICT investments. These findings suggest that falling prices of ICT entail both higher needs and incentives for firms to provide training programmes for high-skilled workers. 


\title{
Do Computers Call for Training? Firm-level Evidence on Complementarities between ICT and Human Capital Investments $\$$
}

\author{
Thomas Hempell
}

(ZEW Mannheim)

\author{
April 2003
}

\begin{abstract}
This paper explores whether investments in information and communication technologies (ICT) and firm-sponsored training programmes are complementary. Three approaches are applied to panel data from German service companies for the time period 1994-98. Results for a system of interrelated factor demands indicate that training complements ICT but not other capital goods. SYS-GMM estimates of production functions reveal that ICT capital is most productive if complemented by training measures in skill-intensive firms. Comparing the impacts on productivity and wage costs shows that ICT raise the profitability of training high-skilled employees.
\end{abstract}

Keywords: Productivity, Training, Information and Communication Technologies, Complementarities, Services, Panel Data

JEL-Classification: C 23, D 24, J 24, J 31

Address: Centre for European Economic Research (ZEW)

Research Group Information and Communication Technologies

P.O. Box 103443

D-68034 Mannheim

Germany

Phone: $\quad+49 / 621 / 1235-233$

Fax: $\quad+49 / 621 / 1235-333$

E-Mail: hempell@zew.de

\footnotetext{
$\S$ This paper was written as part of the research project "Productivity and Spillover Effects from ICT as a General Purpose Technology" commissioned by the Landesstiftung Baden-Württemberg foundation. I would like to thank Irene Bertschek, Werner Smolny, Alexandra Spitz, and Thomas Zwick for helpful comments and discussions.
} 


\section{Introduction}

Various studies have suggested that the rapid diffusion of computers and networks has been contributing to transforming industrialized economies towards 'knowledgebased economies'. The sustained technological advances and price declines in the information and communication technologies (ICT) sector enable firms to radically change their production techniques and internal organisations In recent years, there has been varied evidence in the economic literature that intangible assets like skills, innovation, organisational capital and intellectual property, are crucial for the ability of firms and countries to face the challenges of the ICT revolution $\sqrt{2}$

As argued by Bresnahan, Brynjolfsson and Hitt (2002) and others, complementarities between ICT and intangible assets together with the continuing price declines of ICT goods have been spurring the demand for highly skilled workers. For example, new organisational practices based on ICT help to reshape work tasks towards skill-intensive activities while other, more routinised subtasks are separated out to be done by computers ${ }^{3}$ A variety of studies support this hypothesis pointing to empirical evidence for a substantial skill-bias in ICT-adopting firms ${ }^{4}$

However, the prerequisites for adjusting workers' skill to computers are unlikely to be addressed by simply substituting highly educated for low-skilled workers. Empirical studies suggest that hiring and separations involve substantial adjustment costs, which are particularly high in the case of high-skilled workers (Hamermesh and Pfann, 1996). On the one hand, these costs are due to labour legislation. On the other hand, much of the knowledge related to processes and the internal organisation of businesses tends to be tacit and therefore firm-specific (Nelson and Winter, 1982). New workers must acquire this knowledge. This is often done by formal training courses or on-the-job training.

Training programmes are not only directed towards new workers. In many instances, they are also designed to update skills of current personnel to special applications and changing tasks. Various applications of ICT are designed individually to the environment of companies by linking specific data bases, co-ordinating business processes or interconnecting workplaces, for example. Moreover, resulting re-organisations of processes and the introduction of new products and services may require specific training measures to prepare employees for new specific tasks and skills. To the extent that the corresponding training needs are mainly firm-specific, businesses may have incentives to invest in training their workers $5_{5}^{5}$

\footnotetext{
${ }^{1}$ See for example Brynjolfsson, Hitt and Yang (2002) and Arnal, Ok and Torres (2001).

${ }^{2}$ See, e.g., Brynjolfsson and Hitt (2000) and OECD (2001; 2002b).

${ }^{3}$ Spitz (2003) reports evidence for strong impacts of computer usage on the composition of work tasks in German enterprises.

${ }^{4}$ See Chennells and van Reenen (1999) for a comprehensive overview of the literature on the impacts of new technologies on the demand for educated workers.

${ }^{5}$ This, at least, is a main message from the classical Human Capital theory set forth by Becker (1964). Section 2.1 gives a more differentiated picture of this issue.
} 
Even though several studies have pointed to complementarities between training

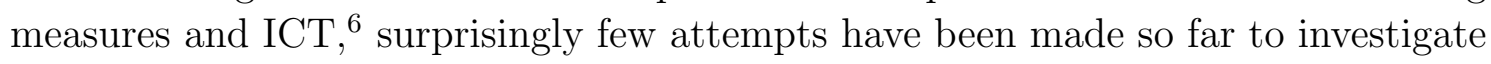
this link empirically. One important exception is the study by Bresnahan et al. (2002) who find strong positive impacts of ICT investments on the demand for skilled workers and firms' investments in human capital. However, the particular role of training remains only a side-aspect of their study.

A more detailed understanding of the interaction between new technologies, education and training is also growing in importance in macroeconomics and in policy-oriented research. Helpman and Rangel (1999) analyse the different roles of technology-specific experience and general knowledge on the growth effects from the adoption of new technologies. Moreover, a recent study by the OECD has pointed to the particular relevance of training for policy makers:

"A skilled labour force is a prerequisite for success in today's economy. The education and training of current workers is likely to be the most effective means of maintaining and upgrading the skills of the current labour force. Given swiftly changing technologies, work methodologies and markets, policymakers in many OECD countries are encouraging enterprises to invest more in training, and to promote more general work-related training of adults.

While much is known about what governments and individuals expend to promote learning within formal education institutions, far less is known about the extent of learning at the workplace or in other settings outside formal education and after the completion of initial education." (OECD, 2002a, p. 247)

The aim of this paper is to assess the link between ICT investments and the need for training in more detail at the firm-level. In a first step, I employ a model of interrelated factor demand to assess the complementarities in the demand for ICT, non-ICT and (intangible) training capital in service firms. I then explore to what extent differing abilities of firms in coordinating investments in ICT and training may lead to productivity advantages. Finally, I consider whether wage reactions entail disincentives for firms to invest in training. For this purpose, I run additional wage cost regressions in order to assess whether the productivity increases from training programmes are offset by corresponding wage increases. A special focus will be directed towards the role of ICT and education in this context. If firms cannot appropriate the benefits from their training investments, this may lead to suboptimal investment in both training and new technologies.

For the empirical assessment of these issues, I use a detailed set of panel data of German firms in business-related and distribution services. These industries are continuously gaining general economic importance and play a key role in the

\footnotetext{
${ }^{6}$ See the literature review in the next section.
} 
specific context of the transformation of industrialised towards knowledge-based economies. In the quantitative analysis, I consider various methodological issues that have been raised in the empirical literature on the productivity of training. First, training expenditures tend to be a long-term investment. Exploiting the longitudinal structure of the data, I construct stocks of tangible and intangible capital from accumulated investment in ICT, non-ICT and from training in order to take potential lags between the time of investment and its productive effects into account. Second, by considering firm-level data both on output and wage costs, I address the question to what extent firms are able to appropriate the productivity gains from their training investments. This issue is important for considering the incentives of firms to invest in training. Third, I take advantage of the panel structure of the data by using system GMM estimators in the production function and wage regressions. By using this approach, I am able to control for various potential biases like unobserved heterogeneity, simultaneity and measurement errors. Finally, I consider the role of education for the ability of workers to adjust their skills in training programmes. The inclusion of education also helps to relate the obtained results to existing studies that assess the conjecture of a skill-bias in labour demand resulting from the diffusion of ICT.

The paper is organised as follows. In the next section, I review the literature and set out some theoretical considerations that help to focus the empirical analysis on specific working hypotheses. Section 3 describes the three empirical approaches, and section 4 discusses the data and statistical descriptives. The results are presented and discussed in section 5 , and section 6 provides some concluding remarks.

\section{Previous literature and theoretical perspectives}

This paper links two economic topics that have been extensively considered segregately in the previous literature: the productivity contributions of ICT investment on the one hand, and productivity and incentives of training programmes on the other. There are, however, only very few attempts to address both issues jointly. In this section, I first survey several studies that have explored questions similar to the ones raised in this paper. Building on these earlier contributions, I then present some theoretical considerations that help to focus the empirical investigation on specific hypotheses concerning the demand for ICT and training as well as the role of formal education.

\subsection{Previous studies}

Various previous studies that investigate the productivity contributions of ICT have pointed to the possibly important role of complementary training for a successful adoption of ICT in firms. Several of these studies have found large implicit returns 
to ICT investment that exceed those of other types of capital..$^{7}$ Brynjolfsson and Hitt (2000) argue that unobserved complementary costs associated with ICT investments (including training expenditures) may explain these differences. If such additional costs are particularly important for ICT but are not included in the econometric analysis, the results will suffer from an omitted variable bias that overstates the true productivity contributions of ICT. Similarly, Brynjolfsson et al. (2002) argue that training expenditures may be interpreted as investments in intangible assets that act as complements to ICT investments. Cummins (2002) interprets training programmes as part of a wider definition of adjustment costs. Once these costs are expended, they implicitly contribute to a firm's organisational capital by causing differences in the valuation of installed and uninstalled capital.

While there is a broad consensus that ICT contributes to firm-level productivity, the empirical evidence on the productivity effects from training programmes are rather mixed, however 8 An important part of this heterogeneity may be due to varying methodological approaches: the decision of invest in training is likely to be endogenous with respect to a firm's performance. Bartel (1994), Dearden et al. (2000) and Zwick (2002) find that it is less productive firms that tend to invest more in training. If this endogeneity is not controlled for in the empirical analysis, the true productivity contributions of training will be understated. This effect from endogeneity is just the reverse of those found in studies on ICT productivity where well-performing firms have been found to invest more in ICT (Brynjolfsson and Hitt, 1996; Hempell, 2002b). Moreover, there may be substantial time lags between the training measures and its contributions to productivity. The effects of training expenditures on contemporaneous productivity might therefore be rather small (Black and Lynch, 1996). Analogue arguments have also been put forward in the literature on the productivity of ICT (Brynjolfsson and Hitt, 2000). One solution to this problem is to construct a training stock from a firm's accumulated training expenditures in the past (Dearden et al., 2000; Ballot, Fakhfakh and Taymaz, 2001a) as well as separate capital stocks for ICT and non-ICT from the accumulated investment expenditures.

An important issue of training programmes is the question about who will have incentives to pay for training: the firm or the worker? The content of the training seems particularly relevant in this context. According to the human capital theory by Becker (1964), firms will be willing to invest mainly in training that is firm-specific. On the contrary, he predicts that the costs of general training will have to be born by the workers due to the threat of poaching. The level of general training may be suboptimally low if the access of workers to credits is constrained by market imperfections. More recent theories, however, argue that frictions and information asymmetries in the job-market may motivate employers to even finance general training of their workers (Acemoglu and Pischke, 1996; Acemoglu, 1997). In an empirical analysis of training measures financed by firms, Barrett and

\footnotetext{
${ }^{7}$ See, e.g., Lehr and Lichtenberg (1999) and Brynjolfsson and Hitt (2001).

${ }^{8}$ See Dearden, Reed and van Reenen (2000) for an extensive review.
} 
O'Connell (2001, p. 658) find that general training yields higher productivity effects than firm-specific training. They consider efficiency wage arguments and the literature on psychological contracts as potential explanations for these findings that obviously conflict with the implications of Becker's work. Autor (2001) points to the importance of self-selection and screening that play a role for temporary help firms to provide their workers with upfront training.9

An alternative way to assess training incentives used in more recent studies is to directly compare output and wage changes resulting from training programmes. Dearden et al. (2000) find that indeed only about a third of the productivity gains from training in British industries are captured by the workers through higher wages. Following a similar approach, Ballot, Fakhfakh and Taymaz (2001b) find for French and Swedish firms that the predominant part of the productivity gains from investment in training (as well as $R \& D$ ) can be appropriated by the investing firm. These results support the case for rather high incentives of firms to pay for training. However, the studies do not distinguish between general or firm-specific training programmes.

Even though the empirical literature on both issues (productivity of ICT on the one hand, and benefits from training on the other) is extensive, indeed, only few empirical efforts have been made to explicitly assess the question whether the increasing diffusion of ICT may increase training incentives for the firms. After all, some studies have reported evidence that ICT investments are often combined with increased training efforts. Brynjolfsson and Hitt (1998) report that firms that invest in ICT intensively train a higher fraction of their workers and screen new employees more intensively for education than less ICT-intensive firms do. Brynjolfsson et al. (2002) find that the share of workers that receive off-the-job training is strongly correlated to various measures of ICT investment and that this correlation is robust to controlling for firm size, worker occupation and industries. Black and Lynch (1996) find significant evidence that employer-provided computer training has a positive and significant effect on productivity in establishments in the service sector (though not in manufacturing). For other forms of training, they do not find any statistically significant productivity impacts. They interpret these findings as evidence that "it is not so much whether you train workers, but rather what you train the workers in that affects establishment productivity" (p. 266).

Workers are not equally able to learn and to update their skills for new tasks opened up by the use of ICT. Some contributions have highlighted the importance of education for the ability of workers to adjust to new technologies. Bartel and Lichtenberg (1987) present firm-level evidence that highly educated workers are better enabled to adjust to and to implement new technologies. Taking a more aggregate view, Baily (2002) points to the importance of a continual development of

\footnotetext{
${ }^{9}$ Offering firm-sponsored training will differentially attract workers of greater unobserved ability (self-selection), while the coupling of training with testing of skills will facilitate the screening of workers' abilities.
} 
skills associated with increasing investments in ICT. He argues that an important source for the growing demand of skilled labour and increasing returns to education in the U.S. economy may be the superior ability of educated workers to acquire new skills and to take advantage of training. Chun (2003) reports evidence that the education of workers facilitates both the adoption and the (continuous) use of information technologies in U.S. industries.

Other studies consider the joint occurrence of ICT usage, organisational changes and training efforts in firms. These analyses are generally embedded in the overall question of whether the combination of ICT usage and re-organisation entail a skill-bias in the demand for workers. Bresnahan et al. (2002) explore the effects of organisational changes, skills of production workers and IT investment on the demand for human capital investment for a sample of approximately 300 large U.S. firms. They proxy human capital investment by a combination of the share of workers involved in training measures and the manager's qualitative assessments of the importance of cross-training workers and pre-employment screens for education. ${ }^{10}$ They find that decentralisation and IT investments are the predominant forces behind investments in human capital, whereas the level of worker skills predicts human capital investments only if organisational changes are omitted from their regressions. Falk (2001) investigates the reverse direction of causation and finds evidence that both investments in ICT and training efforts are the primary forces behind firms' introducing organisational changes in German service firms. These changes in turn are important factors for shifting labour demand towards workers with higher education. Caroli and van Reenen (2001) find that the productivity gains from organisational changes are declining in the firm's share of unskilled workers. They suggest that — jointly with other factors - this result may reflect that the costs of training for multitasking entailed by organisational changes decrease with the skills of workers.

Summing up, the previous empirical literature on ICT and training entails the following lessons. First, ICT is often complemented by other investments that must be taken into account for assessing the productivity effects of ICT. Second, the implementation of new technologies (including ICT) tends to be associated with training efforts and the changes in work tasks can be addressed more easily by high-skilled workers. Third, the incentives for firms to invest in training are theoretically and empirically ambiguous and obviously depend on the specific kind and the aims of the training programmes. Fourth, the omission of firm-specific effects and endogeneity issues in the analysis tends to understate the benefits from training but to overstate the productivity of ICT investments. Fifth, lags between the time of investments and its effects may understate the benefits from either kind of investment if these are not explicitly considered. In the following analysis on the interaction of ICT and training, I will pay special attention to these results.

\footnotetext{
${ }^{10}$ The determinants of the demand for worker training alone are not reported in the study.
} 


\subsection{Theoretical considerations}

The propensity to invest in ICT varies substantially between firms. As shown in the graph in appendix B (page 42) and set out in some more detail in section 4. the share of ICT in total tangible investment varies tremendously even within industries. Given that markets in the ICT-producing sectors are rather competitive, it is very unlikely that these variations are primarily due to price differentials that firms might face in their investment decision. Instead, it is much more likely that these differences mirror differing abilities of firms to make productive use of new technologies. As set out in the review of the literature, these differences may be due to two main sources that in many cases are difficult to disentangle: different endowments with complementary (in particular intangible) assets on the one hand and varying adjustment costs on the other.

If the endowments of firms with complementary assets were variable and could be adjusted easily, these assets would be no important source of disparities in the reaction to falling prices of ICT. When computers and other ICT assets get cheaper, firms will adjust the complements correspondingly and exhibit very similar patterns of demand for new technologies embedded in capital investment. However, while ICT tend to have a relative short life cycle and are replaced quite frequently, various of the potential complements to ICT seem to be less variable. Skills of workers, organisational practices, innovation strategies, intellectual property and so forth, seem to be quasi-fixed in the short term since they involve very high adjustment costs. ${ }^{11}$ Apparently, it is not so much the technical implementation of ICT itself that involves high costs but rather the adjustment of the various intangible assets complementing investments in ICT.

As pointed out in the preceding section, replacement of workers may be a second-best strategy in order to adjust skills to the use of new technologies. Turnover costs tend to be high and firm-specific knowledge may play a crucial role for the need to update skills. Following this reasoning, adjusting skills by training programmes may be a superior instrument in the short term whereas in the medium and long-term firms will also change recruitment strategies and demand more high-skilled workers. However, this shift itself may even be a consequence of rather than an alternative to the increasing need for training efforts. If falling prices of ICT facilitate changes of processes and organisations within firms and if these changes enhance the needs for a continuous adjustment of skills, a skill-bias in the demand for new workers may arise from better learning capabilities if well-educated workers can be trained more effectively to continuously changing work tasks. This argument entails the growing importance of a 'life-long learning' and of formal education as a basis for the ability to learn.

A consequence of this reasoning is that ICT investment, innovations, training and a high level of education may form a cluster of complements that continues

\footnotetext{
${ }^{11}$ See Brynjolfsson et al. (2002).
} 
to grow in importance with falling prices of ICT. In order to point to the role of education as a necessary prerequisite for the ability to aquire new skills, I treat a firm's endowment with educational skills as a quasi-fixed asset that determines the ability to update workers' skills through training programmes. This reasoning slightly expands the scope of the analysis beyond the mere interaction of ICT and training. It additionally includes the question to what extent the educational level of the workforce play a role for the adjustment of skills to new tasks.

Summarising these ideas, the following two hypotheses form the main focus of the subsequent analysis. First, the productivity of ICT is substantially enhanced by complementary training measures. Second, workers with a higher formal educational level can be trained more efficiently.

The expectations about the incentives for firms to pay for training measures are more ambiguous. As found in various previous studies, a substantial part of the changes induced by investments in ICT refer to the organisational structures of firms. As a consequence, ICT-related training measures will be firm-specific if they refer to multi-tasking, specific software applications etc. On the other hand, the training needs might be rather general if organisational changes enhance the importance of interactive and communication skills required for the work in teams, the dealing with customers and suppliers, inspiring and coaching subordinates etc. (Bresnahan et al., 2002). Taking additionally into account that the results in the empirical literature are ambiguous about the incentives of firms to pay for either type of training, it is difficult to assess from a theoretical point of view whether gains from ICT-related training can indeed be appropriated by the firms. This question is thus left open for the empirical investigation without any ex-ante hypothesis.

\section{Empirical approach}

The main topic investigated in this paper concerns the question whether the increasing demand for ICT has been enhancing the training efforts of firms. In the following subsections, I set out three complementary empirical approaches to analyse this question. The first two approaches are aimed at exploring complementarities between ICT and training, whereas the third one assesses the question whether training needs induced by ICT investments may indeed entail higher training incentives for firms.

The suggested complementarity of ICT and training has at least two important implications that can be assessed empirically at the firm-level. A first implication concerns homogenous patterns of factor demand. If adjustment costs associated with ICT and training are small or do not vary significantly, the demand for both inputs will depend on a similar set of determinants and will be highly correlated with each other. A second implication is that joint investments in ICT and training will yield higher productivity contributions than uncoordinated investments in either kind of 
asset. Empirically, this implication can be assessed only if lags, adjustment costs, uncertainties or errors prevent managers from installing a unique optimal combination of complementary factors instantaneously. The resulting heterogeneity in the productivity of factor usage can be explored in a production function framework.

The third approach envisaged in this paper concerns the incentives for firms to invest in training that complements ICT investments. If the productivity gains from such training expenditures are offset by wage increases of a similar magnitude, resulting disincentives will slow down both firms' training efforts and investments in ICT. In the empirical application, it is therefore investigated how the benefits from ICT-related are partitioned to the investing firm and its employees.

\subsection{Interrelated factor demand}

A common way to consider complementarities in the context of firms' factor demand is to take a price-based approach. With perfect markets and without adjustment costs and uncertainties, changes in the demand for inputs will be determined exclusively by the level of output and relative prices. In such a framework, varying factor prices across firms will explain differing input ratios. In this sense, two inputs are complements, if their cross-price effects in the conditional factor demand function are non-positive $\sqrt{12}$ For the context of this study, however, this approach does not seem particularly appropriate for three reasons. First, investments in ICT and training are very comprehensive notions that make it difficult to identify firm-specific prices for ICT (including both hardware and software) and prices for training (which to a substantial part depend on the opportunity costs of foregone productive working hours) in a conceptually convincing manner. Second, data on firm-specific prices are neither available in practical terms. The alternative is to consider industry-specific prices from aggregate statistics. But such statistics are also difficult to obtain and, moreover, can be approximated more easily in an econometric model by the inclusion of corresponding industry dummies.

Finally, adjustment costs and its determinants are likely to play a crucial role for both ICT and training investments at least indirectly. As argued in the previous section, even if adjustment cost for the technical implementation of ICT and the training of workers are small, both kinds of investments will be linked to complementary innovation efforts in practice - like organisational changes or the introduction of new products or processes - which often involve large adjustment costs. Therefore, price differentials across firms (even if they could be measured properly) will explain only a marginal part of differences in factor demand between firms. The investment strategies of firms even within industries differ hugely ${ }^{13}$ and

\footnotetext{
${ }^{12}$ More formally, suppose that the conditional factor demand function $\mathbf{q}(\mathbf{p}, y)$ defines the vector of the cost-minimizing quantities of inputs $\mathbf{q}$ for a given vector of input prices $\mathbf{p}$ and a given level of output $y$. Then the cross price effects $\partial q_{k} / \partial p_{l}=\partial q_{l} / \partial p_{k}$ of complementary inputs $k$ and $l$ are non-positive.

${ }^{13}$ See the graph in Appendix B and the corresponding discussion in the next section.
} 
these differences are unlikely to be the consequence of differentials of relative input prices.

Taking adjustment costs explicitly into account is therefore a more promising approach to assess the varying factor demand. Inputs - in particular intangible ones - that entail large adjustment costs are considered as quasi-fixed inputs that determine the demand for the more variable factors in the short term. For example, innovation projects and organisational changes are often embedded in long-term strategies (Brynjolfsson et al., 2002), changes in the skill-structure (in terms of formal education of the workers) involve high turnover costs and export activities entail varied long-term efforts to prepare foreign markets with advertisment campaigns and to establish corresponding distribution channels. In the following analysis, I consider these variables - together with other firm characteristics as further controls - as quasi-fixed effects that determine the demand for ICT and training.

By contrast, ICT goods and software tend to have large depreciation rates due to the rapid technological advances in the ICT producing sector. The need for frequent replacements makes ICT demand quite flexible. Moreover, as argued above, training may be a more flexible way to adjust workers' skills to new tasks than an increase in turnover of employees. Conventional (non-ICT) capital is much less easy to vary. However, to facilitate comparisons with ICT, the demand for conventional capital is also modelled to be dependent on quasi-fixed assets ${ }^{14}$ The resulting approach of explaining the demand for ICT and training by quasi-fixed inputs is very similar to the one put forward by Bresnahan et al. (2002) but differs from their method mainly in two aspects. First, I also include the demand for non-ICT. Second, I will estimate the demand for the three inputs in an interrelated system of equations instead of considering the factor demands individually.

The econometric model for the factor demand of firm $i$ for the inputs non-ICT $\left(q_{1 i}\right)$, ICT $\left(q_{2 i}\right)$ and training $\left(q_{3 i}\right)$ takes the following form:

$$
\mathbf{q}_{i}=\left(\begin{array}{ccc}
0 & \beta_{12} & \beta_{13} \\
\beta_{21} & 0 & \beta_{23} \\
\beta_{31} & \beta_{32} & 0
\end{array}\right) \mathbf{q}_{i}+\boldsymbol{\Gamma} \hat{\mathbf{q}}_{i}+\alpha Y_{i}+\mathbf{\Theta C}_{i}+\epsilon_{i}
$$

with $\mathbf{q}_{i}=\left(\begin{array}{c}q_{1 i} \\ q_{2 i} \\ q_{3 i}\end{array}\right)$ representing the (log) factor demand of the three inputs. $\hat{\mathbf{q}}_{i}$ is a vector of the quasi-fixed variables (including the lagged share of employees with university degree and vocational training, past innovation efforts and export propensity), $Y_{i}$ denotes the level of output, $\mathbf{C}_{i}$ contains further control variables (firm size, firm size squared, corporate structure, industry and time dummies, regional dummy), and $\epsilon_{i}$ is a vector of normally distributed error terms. Since

\footnotetext{
${ }^{14}$ This problem of restricted variability will be ameliorated in the empirical analysis when investments instead of demanded stocks are considered in additional regressions.
} 
external shocks will affect the demand for all three factors simultaneously, the error terms of the demand equations are correlated. I therefore apply a seemingly unrelated regression (SURE) to estimate this system of equations efficiently.

Of course, the regression results of this model will be strongly driven by the endogeneity of the input factors. This would be a problem if the focus of interest was on some specific causal relationship between our potential complementary assets ICT and training. However, as emphasised by Bresnahan et al. (2002), complementarities can be interpreted in either causal direction. Training may cause ICT investments or ICT investments may cause training. In this sense, the specification in equation 1 should be interpreted as an approach to assess and decompose the correlation of the demand for complements with respect to observed determinants (the quasi-fixed effects and controls) and other unobserved factors (captured by the interrelation terms $\beta_{j k}$ ). These interrelation terms are explicitly aimed at capturing simultaneous reactions in the demand for the variable factors $q$.

Apart from revealing complementarities, the analysis may also help to point to differences in the patterns of determinants of factor demand. For example, the demand for training is expected to depend particularly strongly on the availability of skilled labour whereas for ICT demand, innovational efforts or firm-size (due to potential network effects) might be more relevant. In this sense, the analysis will also help to understand which other factors may prevent firms from choosing a similar combination of ICT and training investment. This heterogeneity in input ratios forms the basis for the production function approach described in the subsequent subsection.

However, it may well be the case that not both of the complements can be implemented equally easily in the firm. To illustrate this point, consider a much more 'classical' pair of complements in production, coal and air. Both inputs are necessary for generating energy. However, since air is ubiquitous, the limiting factor of the two complements will be the availability of coal. In a similar though not equally clear-cut — distinction, one may ask whether the ability to train workers is limiting the demand for ICT or vice versa. Suppose that some external shock — like an increase in demand — will shift out the demand for both complements. Moreover, suppose that adjustment costs for training are higher than those for the technical installation of ICT. In this case, the demand response in both inputs will crucially depend on the ability of adjusting the training stock, such that training will be limitational (and in this sense be causal) for ICT investments. In order to consider such limitational aspects between the complements, I modify the first specification and explicitly control for the endogeneity of the factors. Endogeneity in this context comprises the correlation between the complements that is common to all firms and points to the differing abilities of firms to coordinate the two complements.15 The results

\footnotetext{
${ }^{15}$ This limitational causality is not equivalent to the more general stating that training causes ICT investments. Indeed, it makes much more sense to treat the continuously falling prices of ICT
} 
will reveal whether the critical ingredient of the complementarity is rather ICT or training. This approach thus helps to identify the part of the correlation between ICT and training demand which is due to differences between firms (and that will be exploited in the production function regressions described in the next subsection).

To control for endogeneity, equation (1) is slightly modified in a second specification. First, instead of the stock variables I will consider investment expenditures instead of the stock variables in order to consider more directly the ability to adjust the quantity of inputs in the short-term. Second, I control for endogeneity of the investment demands in this analysis in order to separate out factors that simultaneously impact the ability to invest in both ICT and training. In this specification, a positive influence of training on ICT investments will signal that training efforts are more difficult to accomplish and are therefore a limitational factor to ICT investments. Conversely, ICT would be limitational if its impact on the demand for training was positive.

In order to control for endogeneity in the system of investment demand equations, I use the corresponding stocks of capital as identifying variables. This may be justified by factor-specific adjustment costs: investments that replace existing capital tend to involve lower adjustment costs than investments in new plant capacity 16 Therefore, the existing level of ICT capital serves as an identifying variable for ICT investment, the training stock for training investments and non-ICT stock for investments in non-ICT capital. This modified version of equation (1) is then estimated by three-stage least squares (3SLS).

\subsection{Productive interactions}

An alternative approach to measuring complementarities is to assess the productive interaction more directly in a production function framework. Complementarities imply that the marginal returns to one input increase with the amount of the installed complements. A prerequisite for the production function approach to work is that the inputs are not perfect complements in the sense that other forces like adjustment costs, uncertainties, experimentation or management errors prevent firms from adjusting to one unique optimal combination of factors instantaneously 17 As pointed out before, such distorting factors are likely to play a role for the demand of ICT and training. In response to falling prices of ICT, some firms may be able to

as the exogenous driving force behind the increased training needs. It is important to keep in mind that the 'causality' reflected by the instrumented approach is mainly based on differences between firms in their abilities to adjust to changing environments. Firms with more educated workers, for example, may be better prepared to match falling ICT prices by a joint increase in both ICT investments and (efficient) training of their workers. In this case, the falling prices are the truely exogenous factor, whereas the positive impact of education on the firm's responsiveness reflects the limitational causality revealed by the instrumented approach.

${ }^{16}$ Hamermesh and Pfann (1996) emphasise the relevance of distinguishing between the adjustment costs of gross and net changes in the inputs of firms.

${ }^{17}$ See Caroli and van Reenen (2001) and Bresnahan et al. (2002). 
co-ordinate ICT investments with corresponding training needs more readily than other firms and reap higher productivity gains due to the coordination of the inputs.

The ability to supplement ICT investments by corresponding training measures may depend on the educational background of the workers. If - as argued above - a particular productive advantage of educated workers consists in their ability to adjust to changing work tasks, the combination of education and training will raise the productivity of ICT investments. In this case, the complementarity is three-fold and the ability of firms to accommodate to a 'high-ICT, high training' optimum will rise with the endowment with well-educated workers.

I will analyse the productive interactions of ICT, training and education in a Cobb-Douglas production function framework that is extended by the interactions of the relevant input variables ${ }^{18}$ The resulting econometric specification for the logarithm of output (value added) $y_{i t}$ of firm $i$ in period $t$ is:

$$
\begin{aligned}
y_{i t}= & \beta_{1} l_{i t}+\beta_{2} k_{i t}+\beta_{3} i c t_{i t}+\beta_{4} t_{i t} \\
& +\gamma_{1} s_{h, i t}+\gamma_{2} s_{m, i t}+\Psi^{\prime}\left(i c t_{i t}, t_{i t}, s_{h, i t}, s_{m, i t}\right) \theta+\eta_{i}+\epsilon_{i t}
\end{aligned}
$$

where $l, k, i c t, t$ represent the logarithms of the number of employees, the stocks of non-ICT capital, ICT capital and training, $s_{h}$ and $s_{m}$ are the shares of highly educated and medium skilled workers. $\eta_{i}$ denotes time-invariant unobserved firm-specific effects impacting productivity and $\epsilon_{i t}$ is an asymptotically normally distributed error term. The vector $\boldsymbol{\Psi}\left(i c t_{i t}, t_{i t}, s_{h, i t}, s_{m, i t}\right)$ contains various interactions between the variables for ICT, training and shares of skilled labour that enrich the basic Cobb-Douglas specification (with $\theta$ being the vector of its coefficients).

One key aspect of this study is to assess to what extent the combination of training and ICT usage increase productivity. The interaction of these two variables may be interpreted as the additional productivity gains that can be obtained from specific training measures that supplement ICT investments. ${ }^{19}$ Moreover, the interaction of training and skill-shares may be interpreted to indicate to what extent the training of educated employees yields higher benefits than training unskilled workers, or to what degree training of educated workers is more 'productive'. A threefold interaction of education, training and ICT may then be interpreted as the specific benefits from ICT-related training of highly educated workers. If, first, ICT investments enhances training needs and, second, training educated workers is more productive, and, third, education is particularly important for adjusting to ICT, the interaction of all three inputs will be positive.

\footnotetext{
${ }^{18}$ Similar interactions of only a few selected inputs in a Cobb-Douglas function framework have been analysed in several earlier empirical studies on complementarities, such as Dearden et al. (2000), Bresnahan et al. (2002) and Brynjolfsson et al. (2002).

${ }^{19}$ Due to symmetry, the interaction equally reflects the additional productivity gains from ICT investments that are complemented by investments in training.
} 


\subsection{Training incentives from ICT investment?}

Even though training may raise productivity, incentives of firms to invest in training may be small. If the predominant part of productivity gains from training investments are appropriated by workers through higher wages, and if market failures (e.g. credit constraints) prevent firms from imposing the financial burden on their workers, firms' demand for training will be suboptimal. Such disincentives will also lead to underinvestment in ICT. It is thus important to ask whether computerisation may not only foster training needs but also training incentives for firms.

In order to assess how productivity gains from training are shared by the firm and its employees, I apply a similar approach as in Dearden et al. (2000). I run additional wage regressions in which the log of the total pay roll $w_{i t}$ of firm $i$ in period $t$ is explained by exactly the same inputs that enter the production function:

$$
\begin{aligned}
w_{i t}= & \tilde{\beta}_{1} l_{i t}+\tilde{\beta}_{2} k_{i t}+\tilde{\beta}_{3} i c t_{i t}+\tilde{\beta}_{4} t_{i t} \\
& +\tilde{\gamma}_{1} s_{h, i t}+\tilde{\gamma}_{2} s_{m, i t}+\mathbf{\Psi}^{\prime}\left(i c t_{i t}, t_{i t}, s_{h, i t}, s_{m, i t}\right) \tilde{\theta}+\eta_{i}+\epsilon_{i t}
\end{aligned}
$$

By comparing the elasticities of the inputs in the production function and the wage regressions, I assess the share of the productivity increases from the various types of investments that are appropriated by the workers through higher wages. For example, abstracting from the interactions, $\rho_{4 w}=\tilde{\beta}_{4} / \beta_{4}$ will denote the share of productivity gains from training that are appropriated by the workers and $\rho_{f}=1-\tilde{\beta}_{4} / \beta_{4}$ represents the corresponding share of the firm.

The decision of firms to invest in worker training will be determined mainly by the expected net returns from training investments. These will result from the gross return $r_{t}^{g r}=\beta_{4} Y / T$ minus the return appropriated by workers $r_{t}^{w}=\tilde{\beta}_{4} Y / T$, where $Y / T$ denotes the inverse of the share of the training stock $T$ in output $Y$. The net returns of training to the firm are thus $r_{t}^{f}=\left(\beta_{4}-\tilde{\beta}_{4}\right) Y / T{ }^{20}$ The incentives of firms to raise the training stock due to rising ICT investment will thus not only depend on possibly higher gross returns (reflecting the overall need to complement ICT by training) but rather on potentially higher net returns mirrored by the differential $\beta_{4}-\tilde{\beta}_{4}{ }^{21}$ In order to assess the question whether computerisation of firms leads to increasing training incentives, I will therefore compare the differentials in the

\footnotetext{
${ }^{20}$ Assuming the 'capital costs' of the training stock to be determined by the market interest rate $r$ and the depreciation of the training stock $\left(\delta_{t}\right)$ - consisting in turnover of employees, obsolescence and other factors - , the optimal stock of training $T^{*}$ will result from equating capital costs and expected returns $\left(\delta_{t}+r=r_{t}\right): T^{*}=\frac{\beta_{4}-\tilde{\beta_{4}}}{r+\delta_{t}} \cdot Y$. The demand for training stock $T$ will thus increase in the 'net' elasticity $\left(\beta_{4}-\tilde{\beta}_{4}\right)$ and the desired output level $Y$, and will decrease in the market interest rate $r$ and depreciation $\delta_{t}$.

${ }^{21} \mathrm{~A}$ part of this increase in the optimal training stock due to ICT may be offset by an increase in the rate of depreciation of trained knowledge. If computer related knowledge (like software skills) becomes obsolete more rapidly than training directed towards other purposes, higher training expenditures will be necessary to maintain (rather than increase) the level of the knowledge stock as 'replacement investment'. However, also in this case the use of computers will enhance the
} 
coefficients of the interactions terms in the output and the wage regression. If positive incentives prevail, these differentials will be positive.

\section{Data}

The empirical approaches outlined in the previous section are applied to data from the Mannheim Innovation Panel in Services (MIP-S) which surveys the innovation behaviour of German service firms. ${ }^{22}$ It is conducted annually by the Centre for European Economic Research (ZEW) on behalf of the German federal ministry for education and research and covers a representative sample of more than 2000 firms in business-related and distribution services with at least five employees. The survey methodology is closely related to the guidelines set forth in the Oslo-Manual on innovation statistics (OECD/Eurostat, 1997). The data underlying the study at hand cover the years 1994 to 1998, a period when ICT started to diffuse rapidly in Germany.

The MIP-S contains annual information on basic variables like sales, number of employees in full-time equivalents, total investments, investments in ICT (including expenditures on software), expenditures on training (including costs of foregone working hours), the shares of employees with university degree and with vocational training, and information on whether the firm has introduced new services or new processes in a three-year period. I use additional data from the German statistical office to deflate expenditures with the corresponding price indices. However, official prices for ICT in Germany tend to substantially understate true price declines (Hoffmann, 1998). I therefore employ internationally harmonised deflators provided by Schreyer (2000). Since the survey data do not contain information on intermediate goods, I approximate firms' value added by multiplying firms' sales with the corresponding two-digit industry share of value added in gross output ${ }^{23}$

Basically, investment data could be used to proxy the corresponding capital stocks. However, this is a very noisy measure if time lags (between the time of investment and its becoming productive) as well as cyclical fluctuations (that may strongly impact the investment demand) are important. In order to ameliorate this problem, I make use of the longitudinal structure of the data and use an approach proposed by Hall and Mairesse (1995) to construct separate stocks for the tangible assets non-ICT and ICT capital as well as the intangible training stock ${ }^{24}$

need for continuous training of the employees, and the quantitative assessment of those much more specific aspects are therefore left for future research.

${ }^{22}$ For a comprehensive description of the MIP-S data set and its underlying survey methodology see Janz, Ebling, Gottschalk and Niggemann (2001).

${ }^{23}$ Even though not perfect, this correction helps to control for substantial differences of the value added-to-sales ratio in the different industries. This share is much higher in firms that operate at the end of the value chain (like wholesale and retail trade) than in other services (like consultancies, e.g.). A detailed discussion of the transformations is given in Hempell (2002b).

${ }^{24}$ For the depreciation rates for non-ICT capital, I use industry specific values calculated from 
For the empirical approaches I employ slightly varying samples of the survey. This choice results from the trade-off between the aim of including a larger variety of variables in the factor demand approach on the one hand and the exploitation of the longitudinal structure of the data in the productivity and the wage regressions on the other hand. After dropping observations with item non-responses in the variables of interest, I am left with 1630 observations from 1241 firms for the factor demand approach. The variables included in the factor demand regressions are the (lagged) shares of employees with a university degree, completed vocational training as well as the share of apprentices in the workforce. Moreover, various dummy variables control for further firm strategies: the variables 'exporter' and 'foreign competition' control for whether the firm has reported exports or competition from abroad in one of the observed periods (not necessarily the preceding) ${ }^{25}$, and the variables for continuous innovation of products and processes respectively refer to the innovation strategies of firms. These innovation dummy variables are one if a firm has been reporting a product/process innovation in all the preceding periods (including the current one) that have been surveyed by the MIP-S. For the regressions analysing investment demand, firms' expectation about the development of sales in the corresponding future three-year period are included. Firms were asked to assess on a five-point Likert scale whether they expected sales to grow or fall. Taking the mid-range (no change) as the reference, I constructed four dummy variables that take the value one if sales are expected to grow strongly, grow, fall, or fall strongly. The investment demand is expected to be positively correlated to the expected changes in sales. Further controls include the corporate structure ('part of group of companies'), a regional dummy for East German firms as well as time and industry dummies ${ }^{26}$

One assumption of the model of conditional factor demand is that the skillstructure of firms changes only slowly and may therefore be treated as a quasi-fixed input. Table 9 in Appendix B summarises the average annual changes of the shares of employees with university degree and with vocational training in percentage points and compares these values to the changes in the composition of the capital stocks. The statistics show that in particular the shares of highly skilled workers change by only about 4 percentage points as compared to changes in the composition of the capital stock and the share of workers with vocational training of up to 10 percentage points per year. This finding is consistent with empirical evidence in the literature that adjustment costs of turnovers rise very rapidly with the skills of

data provided by the German Statistical Office. For ICT capital I use an annual depreciation rate of $30 \%$ as derived in Hempell (2002b) and an average growth rate of $40 \%$. For the stock of training, I follow Dearden et al. (2000) who propose a depreciation rate of $15 \%$ and an average growth rate of $2 \%$.

${ }^{25}$ These variables do not refer to previous time periods since the corresponding information is available only for few cross sections. The restriction to previous periods would have strongly increased the number of item non-responses.

${ }^{26}$ The classification of industries with the corresponding NACE codes is summarised in Table 10 in Appendix B. 
the workers (e.g., Hamermesh and Pfann, 1996). While it supports the validity of treating the share of employees with university degree (which is the most relevant group in the context of assessing a skill-bias due to ICT) quasi-fixed, the share of medium-skilled labour is apparently somewhat more flexible than assumed in the model.

For the productivity and wage regressions, panel estimation techniques will be applied that require excluding firms with less than three subsequent observations. Moreover, banks and insurances are dropped from these regressions since the output measures available for these industries (balance sheet totals for banks and total insurance revenues for insurances) are an unreliable measure for productivity calculations. To ensure the consistency of the panel data, I apply various robustness checks. ${ }^{27}$ The resulting panel sample consists of 1249 observations from 393 firms. ${ }^{28}$ The means and standard deviations of the variables of the two samples are summarised in Table 8 in Appendix B. Moreover, Table 10 compares the composition of the samples with each other and with the population of businesses in Germany. The comparison shows that the industry weights in the two samples are very similar and reflect the structure of the population of firms fairly well ${ }^{29}$

Table 1: Training expenditures and investment in ICT and non-ICT

\begin{tabular}{l|lc|cc|c} 
training expenditures & \multicolumn{2}{|c|}{ ICT investment } & \multicolumn{2}{|c|}{ non-ICT investment } & overall \\
per employee (Euro) & low & high & low & high & \\
\hline mean & 787 & 1262 & 1135 & 915 & 1025 \\
median & 108 & 556 & 250 & 278 & 261
\end{tabular}

Results are based on time--averages of investment expenditures from an unbalanced panel 199498 of 4053 firms in business-related and distribution services. Firms are classified as 'high' if the corresponding investment expenditures per worker exceed the median value and as 'low' otherwise.

Since one aspect of the analysis of this paper concerns the correlation of investments in ICT, non-ICT and training, some simple statistics are summarised in Table 1. These statistics are based on the maximum of observations available for these three variables in the period 1994-98. It contains the undeflated time

\footnotetext{
${ }^{27}$ In the longitudinal dimension, firms with unreasonably jumps in sales and employment are excluded from the analysis. This was done on a case-by-case basis, taking into account the size of the firm and the comparison with changes in other periods. In the cross-section, firms with labour productivities (value added per employee) exceeding 500.000 Euros are dropped.

${ }^{28}$ In those regressions that focus on the various interactions in the production function, a slightly bigger sample with 1275 observations from 401 firms is used. The additional observations are obtained from the eight additional firms which did not report information on wages but on the other relevant variables. However, as will be shown, the empirical results are hardly affected by this small sample variation.

${ }^{29}$ Banking and insurances are oversampled in the first sample (used for the factor demand regressions) and - as stated above — omitted in the second sample. In both samples, retail trade businesses are undersampled whereas electronic processing and telecommunication as well as transport and postal services are slightly oversampled.
} 
averages of investment expenditures per worker for 4053 firms. Unlike the samples that are used for the regressions and that contain logarithmic values, this maximum sample includes observations for which investments in one or several of the assets are zero ${ }^{30}$ I divide the sample into groups with 'high' and 'low' investments expenditures using the medians of ICT and non-ICT investments per full-time worker as the classification criterion 31 The statistics indicate that the mean expenditures in training per worker are about $50 \%$ higher in the high-ICT group than in the low-ICT group. The differences are even more pronounced if one considers the corresponding medians of training expenditures. By contrast, this positive correlation cannot be found for conventional (non-ICT) investment and training. Average training efforts are even slightly lower in the 'high-conventional' group. Table 2 supports these results with corresponding correlation coefficients. While ICT and training investments are significantly positively correlated (as well as ICT and non-ICT investments are), there is even a negative (though insignificant) correlation between non-ICT investment and training.

Table 2: Correlations of time-averages of investments per worker

\begin{tabular}{l|lll} 
& non-ICT & \multicolumn{1}{c}{ ICT } & training \\
\hline non-ICT & 1.0000 & & \\
ICT & $0.1071^{* * *}$ & 1.0000 & \\
training & -0.0131 & $0.0871^{* * *}$ & 1.0000
\end{tabular}

The correlations are based on time-averages of investment expenditures from an unbalanced panel of 4053 firms in business-related and distribution services covering the years 1994-98

*** denotes significance at the $1 \%$-level

These simple comparisons yield first support for the conjecture that computers and training might indeed act as complements in the production process. Moreover, the contrasting insignificant correlation between conventional investments and training indicate that the particular need for training is a feature that distinguishes ICT from other kinds of investments in tangible capital.

\footnotetext{
${ }^{30}$ The shares of firms with zero expenditures in all the periods observed are $14.0 \%$ for non-ICT investments, $10.9 \%$ for ICT investments, and $17.3 \%$ for training programmes. Such observations are dropped from the samples that are used for the subsequent regressions presented in the next section 5. As part of the discussion, I will also address the question to what extent the resulting sample selection may bias the econometric results.

${ }^{31}$ The classification 'low' means that the firm's average expenditures on the corresponding investments are below the median and 'high' for the rest of the firms.
} 


\section{Empirical results}

This section presents the empirical results from applying the three approaches set out in section 3 to the MIP-S data. It first presents evidence on the interrelated factor demand of ICT and training, then reports findings on the productive interactions of both inputs in the production process and finally addresses the question whether ICT enhances the incentives for firms to invest in training.

\subsection{Interrelated factor demand}

Based on the empirical model summarised in equation (1), Table 3 reports the results for the interrelated demand based for the three inputs conventional (non-ICT) capital, ICT capital and the training stock. Since external shocks will potentially affect the demand for all three inputs simultaneously, I use the seemingly unrelated regression (SUR) estimator. In this specification, two implications of complementarities can be assessed: first, the investment demand for complements will significantly depend from one another. Second, the patterns of the impacts of the other determinants are expected to be quite similar. Note that this regression specification does not address the question of causality, i.e. whether training causes ICT or ICT causes training (see section 3.1). Instead, these regressions are mainly a more elaborate way to assess correlations between the three types of input demands.

In the first three columns of Table 3, the demands for non-ICT, ICT and training are explained only by the demand for the corresponding two other inputs and the level of output as well as by industry, time dummies and a regional dummy for East Germany. This amounts to assessing the correlation of factor demands within industries in particular years in East and West Germany. The signs and significance levels of the results broadly resemble the simple correlation coefficients as in Table 2. ICT and training are positively correlated whereas the relationship between non-ICT and training is negative. Moreover, the usage of ICT and non-ICT is strongly correlated. One reason for this finding might be that the types of ICT goods and software - like computers or networks - need a 'context' of other types of tangible capital like workplaces, buildings etc. to be installed in. Another reason may be due to credit constraints that are very similar for ICT and non-ICT investments.

In order to explore which underlying factors drive the strong complementarity between ICT and training, I additionally include quasi-fixed assets (corresponding to $\hat{q}_{i}$ in equation 1 in a further specification. The corresponding results reported in the last three columns of Table 3 show that the interrelation coefficients of ICT and training remain statistically significant but are considerably lower than in the first specification ${ }^{32}$ This additional variable thus explains a considerable part of

\footnotetext{
${ }^{32}$ The training coefficient in the ICT equation drops from 0.62 to 0.48 and the ICT coefficient in the training equation from 0.77 to 0.5 .
} 
Table 3: Factor demand of non-ICT, ICT and training

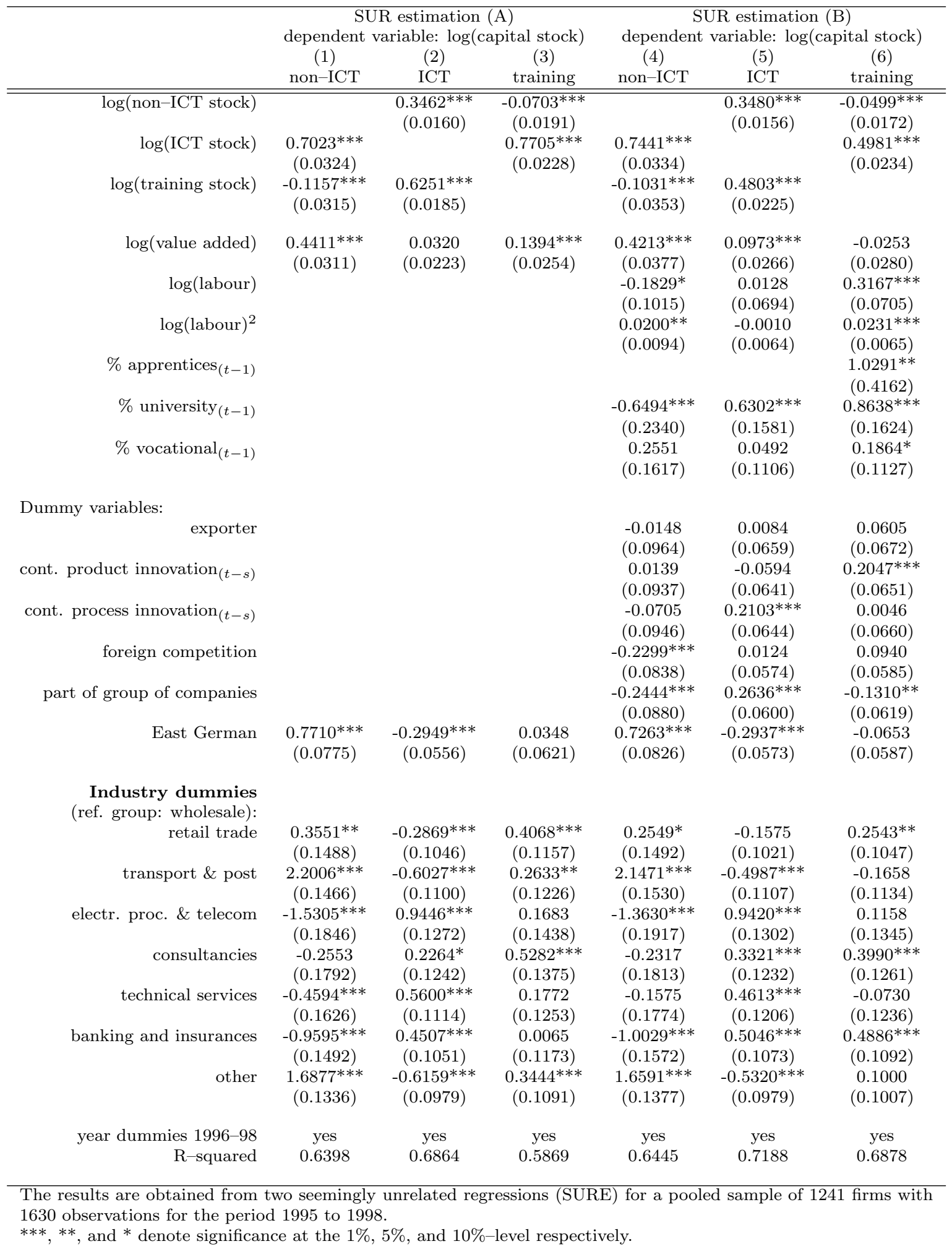


the correlation. By contrast, the other interrelation terms are virtually unchanged.

The results reveal some interesting patterns of the determinants inducing the complementarities between ICT and training. Most importantly, the share of workers with university degree ${ }^{33}$ significantly enhances the demand for both assets but reduces the demand for conventional capital. Similarly, innovation strategies play an important role for the demand for ICT and training but not for non-ICT.

However, training and ICT are not perfect complements and a substantial part of the corresponding demands is determined by varying factors as well. While the demand for ICT is strongly dependent on the level of output, training efforts are determined by the number of employees instead. Both the coefficient of the log of employees and its square are significantly positive. This implies that training efforts are rising more than proportionally with number of employees. This finding may point to spill-over effects of human capital formation in the firms. Moreover, the share of apprentices in the workforce is highly significant for the demand for training 34 This correlation may reflect a firm's general strategy for human capital formation. Employing and instructing apprentices often forms part of a more general recruitment strategy. A high share of apprentices may thus reflect a firm's more general strategy to build up a firm-specific human capital stock.

Even though innovation efforts are important for both ICT and training demand, there are striking differences in the types of innovation. The results show that while training is enhanced by continuous product innovations, ICT demand is obviously closely related to process innovations. ${ }^{35}$ This pattern might be due to the special characteristics of the service sector. Product innovations (incorporating new or significantly improved services introduced by the firms) are closely related to the knowledge of the employees. Examples of new services are the inclusion of a completely new class of products (in wholesale of retail trade), new derivatives offered by banks, new insurance portfolios, or extended support services for telecommunication and software services. Such innovations typically involve the adjustment of the knowledge and the tasks of the employees, and they are likely to be complemented by corresponding training measures. On the other hand, various processes in service firms can be improved and simplified through the usage of ICT, like real-time ordering in trade, the introduction of net-based IT-systems or computer-based consultant systems in banking or insurances. These characteristics of the innovation process in services may help explain the unequal role of product and process innovations for the demand of ICT and training.

A further interesting result concerns the role of corporate structure. Firms that

\footnotetext{
${ }^{33}$ In order to emphasise the properties of the educational level of the workforce as a quasi-fixed asset, I use lagged values for the variables reflecting the educational composition of the workforce.

${ }^{34}$ Additional (not reported) regressions show that the share of apprentices is completely irrelevant for the demand for ICT and non-ICT. Since there is neither a theoretically founded reason why this share would impact these demands, it is included only in the equation for training demand.

${ }^{35}$ A significantly positive impact of past process innovations on the productivity of ICT usage is also found in Hempell (2002a).
} 
Table 4: Investments in non-ICT, ICT and training

\begin{tabular}{|c|c|c|c|c|c|c|}
\hline & \multicolumn{3}{|c|}{ SUR estimation } & \multirow{2}{*}{\multicolumn{3}{|c|}{$\overline{3 S L S}$}} \\
\hline & & & dent variab & & & \\
\hline & (1) & (2) & (3) & (4) & (5) & (6) \\
\hline & non-ICT & ICT & training & non-ICT & ICT & training \\
\hline log(non-ICT investment) & & $0.3258^{* * *}$ & 0.0099 & & $0.0334^{* * *}$ & $0.0216^{*}$ \\
\hline & & $(0.0156)$ & $(0.0171)$ & & $(0.0153)$ & $(0.0114)$ \\
\hline $\log (\mathrm{ICT}$ investment $)$ & $\begin{array}{c}0.7068^{* * *} \\
(0.0339)\end{array}$ & & $\begin{array}{c}0.4337^{* * *} \\
(0.0239)\end{array}$ & $\begin{array}{c}-0.0296 \\
(0.0313)\end{array}$ & & $\begin{array}{l}-0.0109 \\
(0.0215)\end{array}$ \\
\hline $\log$ (training expenditures) & $\begin{array}{c}0.0197 \\
(0.0354)\end{array}$ & $\begin{array}{c}0.4125^{* * *} \\
(0.0228)\end{array}$ & & $\begin{array}{c}0.0320 \\
(0.0242)\end{array}$ & $\begin{array}{c}0.0717^{* * *} \\
(0.0221)\end{array}$ & \\
\hline $\log ($ non-ICT stock) & & & & $\begin{array}{c}0.9102^{* * * *} \\
(0.0151)\end{array}$ & & \\
\hline $\log (\mathrm{ICT}$ stock $)$ & & & & & $\begin{array}{c}0.6886^{* * *} \\
(0.0202)\end{array}$ & \\
\hline $\log$ (training stock) & & & & & & $\begin{array}{c}0.9004^{* * *} \\
(0.0151)\end{array}$ \\
\hline $\log ($ labour $)$ & $\begin{array}{c}-0.1974^{*} \\
(0.1084)\end{array}$ & $\begin{array}{c}0.0183 \\
(0.0736)\end{array}$ & $\begin{array}{c}0.3174^{* * *} \\
(0.0751)\end{array}$ & $\begin{array}{l}-0.0113 \\
(0.0606)\end{array}$ & $\begin{array}{c}-0.0066 \\
(0.0570)\end{array}$ & $\begin{array}{c}0.0170 \\
(0.0418)\end{array}$ \\
\hline $\log (\text { labour })^{2}$ & $\begin{array}{c}0.0202^{* *} \\
(0.0101)\end{array}$ & $\begin{array}{c}0.0065 \\
(0.0068)\end{array}$ & $\begin{array}{c}0.0205^{* * *} \\
(0.0070)\end{array}$ & $\begin{array}{c}0.0120^{* *} \\
(0.0057)\end{array}$ & $\begin{array}{c}0.0131^{* *} \\
(0.0053)\end{array}$ & $\begin{array}{c}0.0042 \\
(0.0039)\end{array}$ \\
\hline $\log$ (value added) & $\begin{array}{c}0.3617^{* * *} \\
(0.0395)\end{array}$ & $\begin{array}{c}0.0963^{* * *} \\
(0.0274)\end{array}$ & $\begin{array}{l}-0.0213 \\
(0.0286)\end{array}$ & $\begin{array}{l}-0.0292 \\
(0.0242)\end{array}$ & $\begin{array}{l}0.0392^{*} \\
(0.0224)\end{array}$ & $\begin{array}{l}-0.0026 \\
(0.0166)\end{array}$ \\
\hline$\%$ apprentices & & & $\begin{array}{c}1.6476^{* * *} \\
(0.4472)\end{array}$ & & & $\begin{array}{c}0.6171^{* *} \\
(0.2552)\end{array}$ \\
\hline$\%$ university & $\begin{array}{c}-0.7468^{* * *} \\
(0.2489)\end{array}$ & $\begin{array}{c}0.5368^{* * *} \\
(0.1678)\end{array}$ & $\begin{array}{c}1.0586 * * * \\
(0.1721)\end{array}$ & $\begin{array}{c}-0.1034 \\
(0.1408)\end{array}$ & $\begin{array}{c}0.1024 \\
(0.1322)\end{array}$ & $\begin{array}{l}0.1849 * \\
(0.0977)\end{array}$ \\
\hline$\%$ vocational & $\begin{array}{c}0.1574 \\
(0.1728)\end{array}$ & $\begin{array}{c}0.0551 \\
(0.1173)\end{array}$ & $\begin{array}{c}0.1910 \\
(0.1199)\end{array}$ & $\begin{array}{l}-0.0918 \\
(0.0965)\end{array}$ & $\begin{array}{l}-0.0017 \\
(0.0908)\end{array}$ & $\begin{array}{l}-0.0098 \\
(0.0663)\end{array}$ \\
\hline exporter & $\begin{array}{c}0.0495 \\
(0.1034)\end{array}$ & $\begin{array}{c}-0.0314 \\
(0.0702)\end{array}$ & $\begin{array}{c}0.0692 \\
(0.0718)\end{array}$ & $\begin{array}{c}0.0572 \\
(0.0576)\end{array}$ & $\begin{array}{c}-0.0132 \\
(0.0542)\end{array}$ & $\begin{array}{c}0.0137 \\
(0.0396)\end{array}$ \\
\hline cont. product innovation & $\begin{array}{c}0.0046 \\
(0.1005)\end{array}$ & $\begin{array}{c}-0.0477 \\
(0.0682)\end{array}$ & $\begin{array}{c}0.1686^{* *} \\
(0.0697)\end{array}$ & $\begin{array}{c}0.0019 \\
(0.0560)\end{array}$ & $\begin{array}{c}-0.0071 \\
(0.0527)\end{array}$ & $\begin{array}{l}-0.0153 \\
(0.0385)\end{array}$ \\
\hline cont. process innovation & $\begin{array}{l}-0.0504 \\
(0.1016)\end{array}$ & $\begin{array}{c}0.2306 * * * \\
(0.0685)\end{array}$ & $\begin{array}{c}0.0634 \\
(0.0705)\end{array}$ & $\begin{array}{c}0.0930 \\
(0.0571)\end{array}$ & $\begin{array}{c}0.1426 * * * \\
(0.0532)\end{array}$ & $\begin{array}{c}0.0904^{* *} \\
(0.0393)\end{array}$ \\
\hline foreign competition & $\begin{array}{c}-0.1642^{*} \\
(0.0898)\end{array}$ & $\begin{array}{l}-0.0454 \\
(0.0610)\end{array}$ & $\begin{array}{c}0.1329^{* *} \\
(0.0624)\end{array}$ & $\begin{array}{c}0.0197 \\
(0.0501)\end{array}$ & $\begin{array}{l}-0.0497 \\
(0.0471)\end{array}$ & $\begin{array}{c}0.0133 \\
(0.0345)\end{array}$ \\
\hline part of group of companies & $\begin{array}{c}-0.2063^{* *} \\
(0.0947)\end{array}$ & $\begin{array}{c}0.2628^{* * *} \\
(0.0641)\end{array}$ & $\begin{array}{l}-0.1027 \\
(0.0663)\end{array}$ & $\begin{array}{c}0.0643 \\
(0.0532)\end{array}$ & $\begin{array}{c}0.1033^{* *} \\
(0.0496)\end{array}$ & $\begin{array}{c}0.0324 \\
(0.0368)\end{array}$ \\
\hline East German & $\begin{array}{c}0.6793^{* * *} \\
(0.0892)\end{array}$ & $\begin{array}{c}-0.2683^{* * *} \\
(0.0612)\end{array}$ & $\begin{array}{c}-0.1119^{* *} \\
(0.0628)\end{array}$ & $\begin{array}{l}-0.0092 \\
(0.0510)\end{array}$ & $\begin{array}{l}-0.0621 \\
(0.0477)\end{array}$ & $\begin{array}{l}-0.0473 \\
(0.0350)\end{array}$ \\
\hline $\begin{array}{r}\text { Expected development } \\
\text { of future sales: }\end{array}$ & & & & & & \\
\hline decreasing strongly & $\begin{array}{c}0.0615 \\
(0.2047)\end{array}$ & $\begin{array}{c}0.0627 \\
(0.1390)\end{array}$ & $\begin{array}{c}-0.2442^{*} \\
(0.1421)\end{array}$ & $\begin{array}{l}-0.0130 \\
(0.1140)\end{array}$ & $\begin{array}{l}0.0810 \\
(0.1073)\end{array}$ & $\begin{array}{c}-0.1717^{* *} \\
(0.0783)\end{array}$ \\
\hline decreasing & $\begin{array}{l}-0.0493 \\
(0.1189)\end{array}$ & $\begin{array}{l}-0.1208 \\
(0.0807)\end{array}$ & $\begin{array}{l}0.1522^{*} \\
(0.0825)\end{array}$ & $\begin{array}{c}0.0089 \\
(0.0663)\end{array}$ & $\begin{array}{l}-0.0429 \\
(0.0623)\end{array}$ & $\begin{array}{l}-0.0188 \\
(0.0456)\end{array}$ \\
\hline increasing & $\begin{array}{l}-0.1582 \\
(0.0973)\end{array}$ & $\begin{array}{c}0.0560 \\
(0.0661)\end{array}$ & $\begin{array}{l}0.1125^{*} \\
(0.0675)\end{array}$ & $\begin{array}{l}-0.0049 \\
(0.0542)\end{array}$ & $\begin{array}{c}0.0529 \\
(0.0510)\end{array}$ & $\begin{array}{c}0.0795^{* *} \\
(0.0373)\end{array}$ \\
\hline increasing strongly & $\begin{array}{c}0.2093 \\
(0.1705)\end{array}$ & $\begin{array}{c}0.0039 \\
(0.1158)\end{array}$ & $\begin{array}{c}0.4236^{* * *} \\
(0.1179)\end{array}$ & $\begin{array}{c}0.2719^{* * *} \\
(0.0953)\end{array}$ & $\begin{array}{c}0.1913^{* *} \\
(0.0897)\end{array}$ & $\begin{array}{c}0.2081^{* * *} \\
(0.0654)\end{array}$ \\
\hline $\mathrm{R}$-squared & 0.5957 & 0.6943 & 0.6643 & 0.8806 & 0.8338 & 0.9018 \\
\hline
\end{tabular}

The results are obtained from a simultaneous estimation by three-stage least squares for a pooled sample of 1241 firms with 1630 observations. In the first step regressions, all exogenous variables are included as regressors. All estimations contain industry and year dummies.

$* * *, * *$, and $*$ denote significance at the $1 \%, 5 \%$, and $10 \%$-level respectively. 
are part of a group of companies have a significantly lower demand for non-ICT and training, but invest much more heavily in ICT than other firms. This positive impact on ICT may be a consequence of network effects that help to make the coordination of activities in groups of companies easier, like the sharing of common databases or the establishment of an intranet.

By contrast, the export activities apparently have no influence on the demand for either of the three inputs considered here. The exposure to foreign competition reduces the demand for non-ICT capital but leaves the demand for ICT and training unaffected. East German firms tend to have a substantially higher demand for conventional capital. This may be a result from the various policy measures aimed at promoting capital spending in the former socialist part of Germany. However, these higher investment activities do not comprise new technologies: the demand for ICT is significantly higher among Western firms.

As pointed out above, the regression results so far assess complementarities between inputs and do not entail a causal relationship between the input demands in one particular direction. The predominant part of the correlation of the demands may be induced by external shocks that simultaneously enhance the demand for both complements. However, it may well be of interest to separate out the impact of such endogenous shocks and to assess 'causalities' in the input decisions. The corresponding estimation will then give insights into the question whether the inputs are limitational with respect to each other. If, for example, the increase in conditional training demand 'causes' firms to invest more in ICT such that this correlation is not due to the endogeneity of both demands, the 'availability' of training is a limitational factor for ICT demand.

Since I assume that in the long run the factor demands of all inputs can be adjusted, it makes more sense to consider the short term investment demands (instead of the capital stocks which results from long term investment behaviour in the past) to assess the limitational relations between the inputs. The corresponding regression results are summarised in Table 4 which consists of two parts. In the first part (first three columns), the regression of Table 3 (cols. 4-6) is replicated with the only exception that the factor demand is now proxied by the current investment expenditures in the three assets rather than the existing capital stocks. Moreover, I also include information on the expected change in sales in the equations of investment demand. While replacement investments are mainly determined by the existing stocks of capital, expectations about changes in sales are likely to be an important determinant also for the decision to increase or reduce production capabilities.

The patterns of the results in the first part of Table 4 exhibit broad similarities with the analogue results from the factor demand involving stocks of input in Table 3. Both the signs and the sizes of the coefficients are very much alike, which supports the robustness of the results. Somewhat surprisingly, the expectations about future sales have a significant impact on training expenditures but not on 
investments in ICT and conventional capital ${ }^{36}$ The only exception are expected strong increases in sales which positively impact all three investment demands.

In the second part of Table 4 (cols. 4-6), I use a three-stage least square (3SLS) estimator to control for the endogeneity of the demands in the systems of equations. This specification uses the corresponding stock variables as identifying variables for the investment demand ${ }^{37}$ The share of apprentices serves as an additional instrument for the firm's training expenditures. All these identifying instrumental variables are highly significant ${ }^{38}$ The interrelation terms of the investment demands are much lower than in the SUR estimation which underlines the importance of simultaneity in the decision to invest in the complements. Most strikingly, the strongest interaction is the significantly positive impact of training on ICT investment. This finding indicates that the training expenditures of firms are limitational for ICT investments. The direct effects of education on ICT demand, however, are insignificantly different from zero but significantly positive for training. This supports the conjecture that education impacts the propensity to invest in ICT mainly through the better possibilities to train workers for changing tasks.

A somewhat surprising result is that in the 3SLS regressions, product innovations are no longer significant for training efforts. Instead, it is process innovations that enhance both ICT and training investments. ${ }^{39}$ In regressions that consider potential selectivity biases, however, both types of innovations are found to impact training expenditures (see below). On the contrary, the positive impact of corporate structure ('part of group of companies') on ICT investment is robust to the instrumentation supporting the interpretation that ICT are particularly well-suited for coordinating activities across associated firms.

One possible objection against the results presented so far may concern biases resulting from sample selection. Since the specification is in logarithms, firms with zero investments in non-ICT, ICT or training are excluded from the analysis. However, further sensitivity analyses show that selectivity biases have only small impacts on the quantitative and no influence on the qualitative results. One

\footnotetext{
${ }^{36}$ This poor performance of the sales-expectation dummies may be a consequence of the heterogenous ways in which firms compile their sales expectation on a five-point Lickert scale. Alternatively, sales expectations may play a rather limited role for investment decisions compared to the other determinants considered.

${ }^{37}$ See section 3.1 on the reasoning behind these instruments. A Hausman test for validity of applying 3SLS (as opposed to robust 2SLS estimation) is not rejected. This is not surprising, however, since - apart from the exclusion of the share of apprentices in the ICT and non-ICT equation - the model is just identified and the results from 2SLS and 3SLS are very similar thus.

${ }^{38}$ To the extent that the existing stocks explain replacement investments, the coefficients of the stocks would be expected to be close to unity (since replacement investments tend to be proportional to the stocks). In fact, the coefficients of non-ICT and training are very close to one (although the statistical test of the coefficients being equal to one are rejected at the conventional significance levels.

${ }^{39}$ This result may be due to the fact that both types of innovations are highly correlated. In $79 \%$ of the observations, both dummy variables were either jointly one or jointly zero.
} 
important exception is that in the regressions entailing selectivity biases both process and product innovations positively impact training expenditures. The detailed results of this sensitivity analysis are discussed in Appendix A of this paper.

Summarising the results from this section, I find strong empirical evidence that the demand for ICT is complemented by corresponding training efforts. Moreover, the requirement of training is a special feature of ICT investments as compared to other tangible investment. There is further evidence that the educational level of the workforce is critical for the investments in training. Training efforts, in turn, are limitational for the investment demand of ICT. Apparently, the educational level of workers affects the demand for new technologies rather indirectly via the training capabilities.

\subsection{Complementarities in the production function}

The results obtained so far have shown that investments in ICT and expenditures in training programmes mutually affect each other. Moreover, the endowment of firms with well-educated employees obviously plays an important role. In order to investigate this relationship between ICT, training and education in more detail, I employ a production function framework as set out in section 3.2. I apply a SYS-GMM estimator as proposed by Arellano and Bover (1995). This estimator takes advantage of the panel structure and uses internal instruments (lagged values) to control for endogeneity. In this estimation strategy, the GMM estimator developed by Arellano and Bond (1991) ${ }^{40}$ is extended by the estimation equation in levels, instrumented by suitably lagged differences of the explanatory variables. These two specifications of the same equation are then estimated simultaneously ${ }^{41}$ This estimator controls for unobserved firm effects, measurement errors in the variables and simultaneity of inputs and outputs. Moreover, as shown by Blundell and Bond (1998a), this estimator substantially improves the performance of the Arellano-Bond estimator in the case of highly persistent variables 42 Apart from the inputs, interacted time and industry dummies are included in the regression to control for industry-specific business cycles and changes in the regulatory environment.

Table 5 reports the results for the production function specified in equation 3$]^{43}$

\footnotetext{
${ }^{40}$ The main idea behind the estimator by Arellano and Bond (1991) is to instrument the equation of interest in first differences by suitably lagged levels of the regressors and to estimate this model by GMM.

${ }^{41}$ The additional moment conditions as compared to the estimator by Arellano and Bond (1991) are not very restrictive. Blundell and Bond (1998b) show that weak assumptions about the initial distribution of the variables suffice. The joint stationarity of the dependent and the independent variables is a sufficient, yet not necessary condition for the validity of the additional moment conditions for the equation in levels.

${ }^{42}$ As shown in Hempell (2002b), the SYS-GMM is particularly more reliable in estimations that explore the productivity effects from ICT than OLS, within or Arellano-Bond estimators are.

${ }^{43}$ I substract the mean of the logarithmic variables from all monetary variables (value added
} 
Table 5: Complementarities between ICT, skills and training

\begin{tabular}{|c|c|c|c|c|c|c|}
\hline \multirow[b]{2}{*}{ inputs (logs) } & \multicolumn{6}{|c|}{ Dep. Variable: $\log$ (value added) } \\
\hline & (1) & (2) & (3) & (4) & (5) & $(6)$ \\
\hline labour & $\begin{array}{c}0.4527 \\
(3.5307)^{* * *}\end{array}$ & $\begin{array}{c}0.5760 \\
(4.4228)^{* * *}\end{array}$ & $\begin{array}{c}0.5818 \\
(5.3226)^{* * *}\end{array}$ & $\begin{array}{c}0.5737 \\
(5.9989)^{* * *}\end{array}$ & $\begin{array}{c}0.5673 \\
(5.9809)^{* * *}\end{array}$ & $\begin{array}{c}0.5746 \\
(5.5702)^{* * *}\end{array}$ \\
\hline ICT capital & $\begin{array}{c}0.0627 \\
(1.8414)^{*}\end{array}$ & $\begin{array}{c}0.0721 \\
(1.3324)\end{array}$ & $\begin{array}{c}0.0956 \\
(1.3752)\end{array}$ & $\begin{array}{c}0.1147 \\
(1.3467)\end{array}$ & $\begin{array}{c}0.0755 \\
(1.4794)\end{array}$ & $\begin{array}{c}0.0955 \\
(1.5308)\end{array}$ \\
\hline non-ICT capital & $\begin{array}{c}0.2301 \\
(2.3011)\end{array}$ & $\begin{array}{c}0.1871 \\
(2.8025)^{* * *}\end{array}$ & $\begin{array}{c}0.1870 \\
(2.9264)^{* * *}\end{array}$ & $\begin{array}{c}0.1985 \\
(3.3109)^{* * *}\end{array}$ & $\begin{array}{c}0.1898 \\
(3.0667)^{* * *}\end{array}$ & $\begin{array}{c}0.1419 \\
(2.6614)^{* * *}\end{array}$ \\
\hline \%university & $\begin{array}{c}0.4117 \\
(0.7002)\end{array}$ & $\begin{array}{c}0.4381 \\
(0.8986)\end{array}$ & $\begin{array}{c}0.3688 \\
(1.2559)\end{array}$ & $\begin{array}{c}0.3219 \\
(1.1355)\end{array}$ & $\begin{array}{c}0.2153 \\
(0.7756)\end{array}$ & $\begin{array}{c}0.3220 \\
(1.1128)\end{array}$ \\
\hline$\%$ vocational & $\begin{array}{c}0.1978 \\
(0.8274)\end{array}$ & $\begin{array}{c}0.3538 \\
(1.5374)\end{array}$ & $\begin{array}{c}0.3287 \\
(2.1142)^{* *}\end{array}$ & $\begin{array}{c}0.3323 \\
(2.2389)^{* *}\end{array}$ & $\begin{array}{c}0.2989 \\
(2.2945)^{* *}\end{array}$ & $\begin{array}{c}0.4406 \\
(2.3383)^{* *}\end{array}$ \\
\hline training & - & $\begin{array}{c}0.1156 \\
(0.9617)\end{array}$ & $\begin{array}{c}0.0873 \\
(0.7818)\end{array}$ & $\begin{array}{c}0.0575 \\
(0.7739)\end{array}$ & $\begin{array}{c}0.1172 \\
(1.0777)\end{array}$ & $\begin{array}{c}0.0616 \\
(0.0061)\end{array}$ \\
\hline $\mathrm{ICT} *$ training & - & - & $\begin{array}{c}0.0063 \\
(0.3423)\end{array}$ & $\begin{array}{c}0.0051 \\
(0.3173)\end{array}$ & $\begin{array}{l}-0.0018 \\
(-0.4019)\end{array}$ & - \\
\hline ICT * \%univ. & - & - & - & $\begin{array}{l}-0.0423 \\
(0.1785)\end{array}$ & $\begin{array}{c}0.0349 \\
(0.1304)\end{array}$ & - \\
\hline training * \%univ. & - & - & - & $\begin{array}{c}0.0461 \\
(-0.0406)\end{array}$ & $\begin{array}{l}-0.1033 \\
(-0.4342)\end{array}$ & $\begin{array}{l}-0.0293 \\
(0.2040)\end{array}$ \\
\hline training $*$ \%univ. $*$ ICT & - & - & - & - & $\begin{array}{c}0.0400 \\
(1.8528)^{*}\end{array}$ & $\begin{array}{c}0.0491 \\
(2.1857)^{* *}\end{array}$ \\
\hline training $* \%$ voc. & - & - & - & - & - & $\begin{array}{c}0.1066 \\
(1.8624)^{*}\end{array}$ \\
\hline training $* \%$ voc. $*$ ICT & - & - & - & - & - & $\begin{array}{l}-0.0035 \\
(-0.4326)\end{array}$ \\
\hline $\mathrm{R}$-square & 0.8700 & 0.8783 & 0.8799 & 0.8800 & 0.8810 & 0.8824 \\
\hline $\begin{array}{l}\text { Sargan ( } \mathrm{p} \text {-values) } \\
\text { errors ( } \mathrm{p} \text {-values): }\end{array}$ & 0.425 & 0.174 & 0.227 & 0.884 & 0.960 & 0.890 \\
\hline $\mathrm{AR}(1)$ & 0.053 & 0.011 & 0.007 & 0.005 & 0.006 & 0.004 \\
\hline $\operatorname{AR}(2)$ & 0.820 & 0.535 & 0.426 & 0.439 & 0.465 & 0.316 \\
\hline
\end{tabular}

Results are based on the two-step SYS-GMM estimator and contain a constant as well as interacted time and industry dummies. T-values reported in brackets are obtained from the first-step estimation results (see Arellano and Bover, 1995). The signs of the coefficients and the corresponding t-values may therefore differ in some cases. The underlying sample consists of 401 service firms with a total of 1275 observations covering the years 1994-98.

$* * *, * *$, and $*$ denote significance at the $1 \%, 5 \%$, and $10 \%-$ level respectively.

In all columns, the point estimates for the (not-interacted) inputs labour, non-ICT and ICT fit the relative shares of the factors in aggregate income statistics fairly well (only the labour coefficient is smaller than the expected of about two thirds). In the sequence of the columns (1) to (6) additional variables and interactions are subsequently included in the specification.

In column 1 , the shares of employees with university degree (\% university) and vocational training (\% vocational) have a positive though not significant 44 impact

and capital stocks, including training stock). This is equivalent to a rescaling of the original (non$\log$ ) monetary units. For the simple (non-interacted) regressors, this does not affect the results of the estimated coefficient except the constant. For some of the interaction terms, however, the centering around the mean is important since arbitrary scaling will affect the corresponding results. All estimation are computed using the DPD98 programme developed by Arellano and Bond (1998) running in GAUSS. For all results, heteroskedasticity-consistent standard errors are reported.

${ }^{44}$ In Table 5 , the point estimates from the efficient two-step estimation are reported. However, the standard errors obtained from this procedure have been argued to be unreliable for hypothesis testing (Arellano and Bover, 1995; Blundell and Bond, 1998b). Therefore, the t-values obtained 
on output 45 In the specification underlying column 2, the accumulated training efforts by the firms in terms of the calculated training stocks ("training") are added to the model. The elasticity of training is quantitatively substantial (0.115) but fails to be significant at the usual levels. ${ }^{46}$ This may be partly due to the relatively small number of observations. The point estimate of ICT is only slightly affected by the inclusion of the training variable. However, the standard error of the coefficient is enlarged such that the impact of ICT is not significantly different from zero anymore. This loss of precision may indeed arise from the complementary relation between ICT and training and the resulting collinearity between both variables 47

In column 3, an additional interaction term between ICT capital and training is added to the specification. However, the interaction results turn out to be very small and insignificant. This may mean that there are no additional productivity gains from a joint usage of ICT and training. Alternatively, the relation may be more complex, involving more factors. As discussed in the theoretical part, the education of the workforce may play an additional role in the interaction between ICT and training. In order to explore this conjecture in more detail, further bilateral interactions between these variables are added (see column 4). However, also the joint consideration of these interactions fails to to be significant.

As pointed out in section 2.2, the coordination of various complementarities required by a successful implementation of ICT are far from being easy. In order to assess whether the joint adaption of ICT, high skills and training measures is the key to a productive use of ICT, an interaction of all three variables is added in a further specification (column 5 of Table 5). The most striking result from this regression is that this joint interaction term of training, \% university, and ICT is

from the one-step estimation are reported as a guide for the statistical significance of the estimates.

${ }^{45}$ As exposed in Hempell (2002b), the ratio of the coefficients of labour input $\mathrm{L}\left(\gamma_{1}\right)$ and the shares of skilled labour $\left(\beta_{1}\right.$ and $\left.\beta_{2}\right)$ may be interpreted as the productivity differential between of the skilled employees as opposed to unskilled workers (reference group). The results obtained here imply that employees with university degree are $91 \%$ and workers with vocational training $44 \%$ more productive than workers without formal education. These values are slightly lower than those obtained in Hempell (2002b) for a substantially bigger sample of service firms obtained from the same data source as here.

${ }^{46}$ This value implies returns to training of $147 \%$ (resulting from $0.1156 / 0.07825$, where the latter value is the average share of the training stock in value added). These are very high returns that point to further expenses that are related to training but are not accounted for in this study. However, the returns are substantially smaller than those found by Ballot et al. (2001a) for France $(288 \%)$ and Sweden $(441 \%)$ in a comparable analysis.

${ }^{47}$ In further regressions, I also explored potential biases that may be induced by endogeneity and lagged effects of training. For this purpose, I first re-ran specification (2) treating training as exogenous instead of using lagged values as instruments. While the two-step result is hardly affected by this change, the one-step coefficient is substantially lower and estimated less precisely than in the instrumented version. Second, I estimated specification (2) using current training expenditures rather than the training stock. In this specification, the coefficient of training is substantially lower than in column (2) of Table 5 and becomes even negative. These two specification checks show that it is indeed important to take into account the endogeneity of training investments as well as lags between training investments and productive effects. These findings are consistent with similar findings in previous studies mentioned in section 2.1 . 
both statistically and economically significant whereas the individual contributions of these three inputs as well as their pair-wise interactions are insignificant. This finding suggests that the productivity of ICT usage is indeed linked to the joint availability of a high-skilled workforce and the conducting complementary training measures.

In order to explore the joint interaction of education, training and ICT usage in more detail, column 6 reports the result for the regression including also interactions between firm training, ICT usage and medium skilled workers. The bilateral interactions between ICT and training on the one hand and ICT and education on the other (which were insignificant in the specifications as of cols. 4 and 5) are excluded from this regression to keep the specification tractable ${ }^{48}$ The most striking result is that also in this specification the threefold interaction of high-skilled labour, training and ICT is highly significant whereas the two-fold interaction of high skills and training is not. The reverse is true for the interactions that include medium-skilled workers. At the same time, the direct (not interacted) productivity from a higher share of medium-skilled workers slightly exceed the direct contributions from highly educated workers. These findings further support the conjecture that ICT investment affects the training needs of well educated employees but not of other skill groups 49

Jointly, the results for the production function approach yield support for the conjecture that the productive use of ICT requires both high-skilled workers and substantial training efforts by firms. Moreover, the findings indicate that also beyond the usage of ICT, training efforts by firms are most successful in terms of productivity gains if combined with a high share of educated employees. By contrast, the direct productivity contributions of highly educated employees do not exceed those of medium-skilled ones once interactions with training and ICT are taken into account. Put together, these findings imply that the overall higher productivity of high-skilled labour is rather indirect and results mainly from their ability to be trained easily, in particular in combination with the usage of ICT.

\footnotetext{
${ }^{48}$ In unreported regressions (analogue to col. 6) that include also these bilateral interactions, the point estimate of the interaction between ICT, high-skilled labour and training remains unchanged but exhibits much higher standard errors of all the interaction terms making them appear all insignificantly different from zero. This feature points to problems of multicollinearity resulting from the inclusion of too many interaction terms.

${ }^{49}$ In further unreported regressions, I also include the two-fold interactions between skills, training and ICT capital. All the additional interactions compared to the specification (6) turn out to be insignificantly different from zero (except for a negative interaction term between ICT and high-skilled labour) while corroborating the main results reported for the more parsimonious specification. Finally, I ran specification (6) employing ICT and training values per employee for the interaction terms. Again, the results were hardly affected. The point estimates of the interaction between ICT, training and high-skilled labour (0.0537) is slightly higher than in the reported specification. However, all coefficients are estimated much less precisely and the corresponding t-values - except the one for non-ICT capital — do not reach statistical significance.
} 


\subsection{Wage effects and training incentives}

The third approach that is explored empirically in this subsection concerns the question whether the incentives to invest in training of the employees is enhanced by the continuing diffusion of ICT. As set out in section 3.3, I address this question by comparing the productivity gains with the changes in the wage costs.

Table 6 replicates two particular productivity regressions from Table 5 (cols. 2 and 6) and compares the results to the coefficients of analogue wage regressions. The production function estimates differ slightly from those of Table 5 since item non-responses in the total payroll reduce the new sample to 393 considered firms. As the direct comparison of the two tables show, the point estimates and significance levels of the coefficients are quite robust to this change in the sample.

The first two columns of Table 6 are based on the Cobb-Douglas function (including the skill shares and the training stock) without the interaction terms ${ }^{50}$ The results suggest that about half of the productivity gains assigned to ICT capital are offset by corresponding wage increases ${ }^{51}$ This share is even higher for non-ICT capital. These positive impacts of investments on wage costs may reflect higher skill requirements associated with capital deepening. The payroll increases from a higher share of highly skilled workers (with university degree) even exceed the corresponding output gains. On the contrary, the productivity gains from training clearly exceed the wage increases assigned to training. Only about a third of the productivity gains are offset by higher wage costs. This ratio is practically the same as the one reported by Dearden et al. (2000) for British industries. Note, however, that the corresponding coefficients of skills and training are estimated very imprecisely.

In the regressions as of columns (3) and (4), the specification is further enriched by the various interactions of ICT, training and education as in the last column of Table 5. In this specification, both the productivity and the wage effects from training alone are virtually zero and the impacts of ICT are similar to the previous estimates. Regarding the interaction terms, there are both similarities and differences between the impacts on productivity and on wage costs. The interaction of training and the share of employees with university degree impact both variables. However, the impact on productivity is strongly affected by the level of ICT usage (significantly positive three-fold interaction) whereas for the wage cost effects ICT plays a minor role. This can be interpreted as evidence that a more intensive usage of ICT increases the net returns for

\footnotetext{
${ }^{50}$ Some readers may find it easier to interpret the results for the corresponding values of output, wages, and inputs per worker. However, as long as the logarithm of employees is kept as an explanatory variable to allow for deviations from constant returns to scale, the coefficients and significance levels of all variables (except the log of labour) are identical in such a transformed regression. Therefore, the results for the coefficients can be equally interpreted as the impacts of the various investments on labour productivity and average wages.

${ }^{51}$ This share is calculated from the ratio of the ICT coefficient in the wage regression and the corresponding coefficient in the production function regression.
} 
Table 6: Comparison of productivity and wage effects of investments in ICT and training

\begin{tabular}{|c|c|c|c|c|}
\hline & $\begin{array}{c}(1) \\
\log (\mathrm{VA}) \\
\end{array}$ & $\begin{array}{c}(2) \\
\log (\text { wage }) \\
\end{array}$ & $\begin{array}{c}(3) \\
\log (\mathrm{VA}) \\
\end{array}$ & $\begin{array}{c}(4) \\
\log (\text { wage }) \\
\end{array}$ \\
\hline$\overline{l o g \text { (labour) }}$ & $\begin{array}{c}0.4783 \\
(3.9296)^{* * *}\end{array}$ & $\begin{array}{c}0.7628 \\
(8.9824)^{* * *}\end{array}$ & $\begin{array}{c}0.4924 \\
(5.2103)^{* * *}\end{array}$ & $\begin{array}{c}0.8548 \\
(14.5264)^{* * *}\end{array}$ \\
\hline $\log (\mathrm{ICT})$ & $\begin{array}{c}0.1033 \\
(1.3444)\end{array}$ & $\begin{array}{c}0.0493 \\
(0.6010)\end{array}$ & $\begin{array}{c}0.0797 \\
(1.5790)\end{array}$ & $\begin{array}{c}0.0370 \\
(0.7512)\end{array}$ \\
\hline $\log ($ non-ICT $)$ & $\begin{array}{c}0.2355 \\
(2.6743)^{* * *}\end{array}$ & $\begin{array}{c}0.1676 \\
(3.1188)^{* * *}\end{array}$ & $\begin{array}{c}0.1874 \\
(2.6502)^{* * *}\end{array}$ & $\begin{array}{c}0.0943 \\
(3.0983)^{* * *}\end{array}$ \\
\hline \%university & $\begin{array}{c}0.2186 \\
(0.4467)\end{array}$ & $\begin{array}{c}0.4022 \\
(1.7274)^{*}\end{array}$ & $\begin{array}{l}-0.0033 \\
(0.7048)\end{array}$ & $\begin{array}{c}0.4916 \\
(3.2328)^{* * *}\end{array}$ \\
\hline$\%$ vocational & $\begin{array}{c}0.2832 \\
(1.4269)\end{array}$ & $\begin{array}{c}0.0467 \\
(-0.2609)\end{array}$ & $\begin{array}{c}0.3146 \\
(2.2818)^{* *}\end{array}$ & $\begin{array}{c}0.1855 \\
(1.5036)\end{array}$ \\
\hline $\log ($ training $)$ & $\begin{array}{c}0.1246 \\
(1.2435)\end{array}$ & $\begin{array}{c}0.0400 \\
(1.1507)\end{array}$ & $\begin{array}{c}0.0760 \\
(0.1370)\end{array}$ & $\begin{array}{c}0.0170 \\
(-0.2710)\end{array}$ \\
\hline $\log ($ training $) * \%$ univ. & - & - & $\begin{array}{l}-0.0357 \\
(0.2438)\end{array}$ & $\begin{array}{c}0.0564 \\
(1.7591)^{*}\end{array}$ \\
\hline $\log ($ training $) * \%$ univ. $* \log (\mathrm{ICT})$ & - & - & $\begin{array}{c}0.0603 \\
(2.5255)^{* *}\end{array}$ & $\begin{array}{c}0.0169 \\
(0.7554)\end{array}$ \\
\hline $\log ($ training $) * \%$ voc. & - & - & $\begin{array}{c}0.1286 \\
(1.9531)^{*}\end{array}$ & $\begin{array}{c}0.0310 \\
(1.5663)\end{array}$ \\
\hline $\log ($ training $) * \%$ voc. $* \log (\mathrm{ICT})$ & - & - & $\begin{array}{c}0.0028 \\
(-0.1876)\end{array}$ & $\begin{array}{c}-0.0073 \\
(-0.7474)\end{array}$ \\
\hline $\begin{array}{l}\mathrm{R} \text {-square } \\
\text { time and ind. dummies }\end{array}$ & $\begin{array}{c}0.8760 \\
\text { yes }\end{array}$ & $\begin{array}{l}0.9386 \\
\text { yes }\end{array}$ & $\begin{array}{c}0.8830 \\
\text { yes }\end{array}$ & $\begin{array}{c}0.9532 \\
\text { yes }\end{array}$ \\
\hline $\begin{array}{l}\text { Sargan stat. ( } \mathrm{p} \text {-values) } \\
\quad \text { errors ( } \mathrm{p} \text {-values): }\end{array}$ & 0.158 & 0.489 & 0.980 & 0.983 \\
\hline $\mathrm{AR}(1)$ & 0.031 & 0.164 & 0.026 & 0.084 \\
\hline $\operatorname{AR}(2)$ & 0.398 & 0.483 & 0.252 & 0.563 \\
\hline
\end{tabular}

Results are based on the two-step SYS-GMM estimator and contain a constant as well as interacted time and industry dummies. T-values reported in brackets are obtained from the first-step estimation results (see Arellano and Bover, 1995). The underlying sample consists of 393 service firms with a total of 1249 observations.

"VA" denotes value added, and "wage" total wage costs of firms as explanatory variables.

firms from training highly skilled employees. As far as the interaction between training and medium skilled workers (\% voc.) is concerned, the productivity effects clearly exceed the wage impacts. Moreover, the impact of the three-fold interaction on productivity and wages is practically equal to zero for this skill group.

These results may be interpreted as evidence that ICT usage not only increases the productivity need for training but also fosters the incentives for firms to pay for training. Moreover, the complementarity between ICT, training and high-skilled labour implies that continuously falling prices of ICT equipment may not enhance the training efforts but may also shift labour demand to more highly skilled employees.

The underlying reasons for the ability of firms to appropriate the gains from 
ICT-related training of highly skilled employees are difficult to identify from the empirical results since additional information would be required for this purpose. However, the factor demand regressions in the previous subsection revealed that process innovations in firms play an important role for the demand of ICT. To the extent that new processes require the updating of firm-specific knowledge of the employees, this might explain the increased training incentives for firms.

\section{Conclusions}

Over the last decades, the continuously falling prices of ICT have been spurring the demand for ICT investments dramatically and this development is likely to continue (e.g., Manasian, 2003). Earlier studies have found evidence that the increasing investments in ICT are accompanied by a variety of complementary innovational efforts, like organisational changes as well as product and process innovations (e.g., Bresnahan and Greenstein, 1996; Bresnahan et al., 2002; Hempell, 2002a). Such changes and innovations have been found to be skill-biased, enhancing the needs for investments in human capital and leading to a demand shift towards skilled labour (e.g., Caroli and van Reenen, 2001; Bresnahan et al., 2002; Falk, 2001).

In this paper, I have explored whether the adoption of ICT enhances the incentives of German services firms to invest in training their employees. The results that I obtained from applying three complementary approaches to data from German business-related and distribution services firms unambiguously approve this conjecture. First, the demand for ICT - unlike non-ICT — is strongly correlated with the demand for firm-paid training. Further explorations revealed that the training stock is indeed limitational for ICT investments. Second, the productivity gains from training are highest in firms that employ a high fraction of employees with university degree and that have been investing strongly in ICT. Third, the share of the productivity gains from training that can be appropriated by the firm is increasing in the stock of ICT.

The results from this study are consistent with earlier empirical work on the productivity gains from ICT and training as well as studies on the skill bias of new technologies. By combining approaches from various strands of the literature, however, I presented some new evidence as well. First, ICT investments do not only entail a higher need for human capital investments but also foster the incentives for firms to pay for training programmes. Second, the ability of firms to reap productivity gains from ICT and training is crucially determined by the availability of suitably educated workers. These findings suggest that in the context of new technologies, the primary contribution of education in the production process may be the inherent ability of workers to learn and to adapt to changing work tasks more easily. This implies that the skill-bias resulting from ICT investments may thus be rather indirect: ICT requires complementary training, but the productivity of training workers depends strongly on formal education. 
Jointly, these findings point to a dynamic role of education in knowledge-based societies. The rapid technological advances in particular in the ICT sector favour continuous changes in work tasks in broad parts of the economy. These changes call for a continuous adjustment of skills and the readiness for a 'life-long learning' by workers. Training programmes by firms are substantially contributing to these adjustments. A key prerequisite, however, is the provision of good education systems which form the basis for successful training facilities in firms. 


\section{References}

Acemoglu, D. (1997). Training and Innovation in an Imperfect Labour Market, Review of Economic Studies 64: 445-464.

Acemoglu, D. and Pischke, J.-S. (1996). Why Do Firms Train? Theory and Evidence, NBER Working Paper 5608, National Bureau of Economic Research.

Arellano, M. and Bond, S. (1991). Some Tests of Specification for Panel Data: Monte Carlo Evidence and an Application to Employment Equations, Review of Economic Studies 58: 277-297.

Arellano, M. and Bond, S. (1998). Dynamic Panel Data Estimation Using DPD98 for GAUSS: A Guide for Users. ftp://ftp.cemfi.es/pdf/papers/ma/dpd98.pdf.

Arellano, M. and Bover, O. (1995). Another Look at the Instrumental Variable Estimation of Error-Components Models, Journal of Econometrics 68: 29-51.

Arnal, E., Ok, W. and Torres, R. (2001). Knowledge, Work Organisation and Economic Growth, OECD Labour Market and Social Policy Occasional Papers 50, OECD. DEELSA/ELSA/WD(2001)3.

Autor, D. H. (2001). Why Do Temporary Help Firms Provide Free General Skills Training?, Quarterly Journal of Economics 116(4): 1409-1448.

Baily, M. N. (2002). Distinguished Lecture on Economics in Government: The New Economy: Post Mortem Or Second Wind?, Journal of Economic Perspectives 16(2): 3-22.

Ballot, G., Fakhfakh, F. and Taymaz, E. (2001a). Firms' Human Capital, R\&D and Performance: a Study on French and Swedish Firms, Labour Economics 8: $443-462$.

Ballot, G., Fakhfakh, F. and Taymaz, E. (2001b). Who Benefits from Training and R\&D? The Firm or the Workers? A Study on Panels of French and Swedish Firms, mimeo.

Barrett, A. and O'Connell, P. J. (2001). Does Training Generally Work? The Returns to In-Company Training, Industrial and Labor Relations Review 54(3): 647-662.

Bartel, A. (1994). Productivity Gains from the Implementation of Employee Training Programs, Industrial Relations 33: 411-425.

Bartel, A. P. and Lichtenberg, F. R. (1987). The Comparative Advantage of Educated Workers in Implementing New Technology, Review of Economics and Statistics 59(1): 1-11.

Becker, G. S. (1964). Human Capital, Columbia University Press, Chicago. 
Black, S. E. and Lynch, L. M. (1996). Human Capital Investment and Productivity, American Economic Review 86/2: 263-267.

Blundell, R. and Bond, S. (1998a). GMM Estimation with Persistent Panel Data: an Application to Production Functions, Working Paper Series No. W99/4, Institute for Fiscal Studies.

Blundell, R. and Bond, S. (1998b). Initial Conditions and Moment Restrictions in Dynamic Panel Data Models, Journal of Econometrics 87: 115-143.

Bresnahan, T. and Greenstein, S. (1996). Technical Progress and Co-invention in Computing and in the Uses of Computers, Brooking Papers on Economic Activity, Microeconomics pp. 1-77.

Bresnahan, T. F., Brynjolfsson, E. and Hitt, L. M. (2002). Information Technology, Workplace Organization, and the Demand for Skilled Labor: Firm-Level Evidence, Quarterly Journal of Economics 117: 339-376.

Brynjolfsson, E. and Hitt, L. (1996). Paradox Lost? Firm-level Evidence on the Returns to Information Systems Spending, Management Science 42/4: 541558.

Brynjolfsson, E. and Hitt, L. M. (1998). Information Technology and Organizational Design, mimeo, MIT Sloan School of Management. http://ebusiness.mit.edu/erik/ITOD.pdf.

Brynjolfsson, E. and Hitt, L. M. (2000). Beyond Computation: Information Technology, Organizational Transformation and Business Performance, Journal of Economic Perspectives 14: 23-48.

Brynjolfsson, E. and Hitt, L. M. (2001). Computing Productivity: Firm-Level Evidence, mimeo, University of Pennsylvania, Wharton School.

Brynjolfsson, E., Hitt, L. M. and Yang, S. (2002). Intangible Assets: Computers and Organizational Capital, Brookings Papers on Economic Activity 1: 137-198.

Caroli, E. and van Reenen, J. (2001). Skill-Biased Organizational Change? Evidence from a Panel of British and French Establishments, Quarterly Journal of Economics 116(4): 1449-1492.

Chennells, L. and van Reenen, J. (1999). Has Technology Hurt Less Skilled Workers?, Working Paper No. 99/27, Institute for Fiscal Studies.

Chun, H. (2003). Information Technology and the Demand for Educated Workers: Disentangling the Impacts of Adoption Versus Use, The Review of Economics and Statistics 85(1): 1-8.

Cummins, J. G. (2002). A New Approach to the Valuation of Intangible Capital, paper presented at EARIE annual conference 2002, 5.-8. September 2002, Madrid, mimeo. 
Dearden, L., Reed, H. and van Reenen, J. (2000). Who Gains When Workers Train? Training and Corporate Productivity in a Panel of British Industries, IFS Working Paper No. 00/04, Institute for Fiscal Studies.

Falk, M. (2001). Organizational Change, New Information and Communication Technologies and the Demand for Labor in Services, ZEW Discussion Paper No. 01-25, Centre for European Economic Research (ZEW).

Hall, B. H. and Mairesse, J. (1995). Exploring the Relationship Between R\&D and Productivity in French Manufacturing Firms, Journal of Econometrics 65: 263293.

Hamermesh, D. S. and Pfann, G. A. (1996). Adjustment Costs in Factor Demand, Journal of Economic Literature 34: 1264-1292.

Heckman, J. J. (1976). The Common Structure of Statistical Models of Truncation, Sample Selection, and Limited Dependent Variables and a Simple Estimator for such Models, Annals of Economic and Social Measurement 5: 475-592.

Heckman, J. J. (1979). Sample Selection Bias as a Specification Error, Econometrica 47(1): 153-161.

Helpman, E. and Rangel, A. (1999). Adjusting to a New Technology, Journal of Economic Growth 4: 359-383.

Hempell, T. (2002a). Does Experience Matter? Innovation and the Productivity of ICT in German Services, ZEW Discussion Paper 02-43, Centre for European Economic Research. (ftp://ftp.zew.de/pub/zew-docs/dp/dp0243.pdf).

Hempell, T. (2002b). What's Spurious, What's Real? Measuring the Productivity of ICT at the Firm-Level, ZEW Discussion Paper 02-42, Centre for European Economic Research. (ftp://ftp.zew.de/pub/zew-docs/dp/dp0242.pdf).

Hoffmann, J. (1998). Problems of Inflation Measurement in Germany, Discussion Paper No. 01-98, Economic Research Centre of the Deutsche Bundesbank.

Janz, N., Ebling, G., Gottschalk, S. and Niggemann, H. (2001). The Mannheim Innovation Panels (MIP and MIP-S) of the Centre for European Economic Research (ZEW), Schmollers Jahrbuch 121: 123-129.

Lehr, B. and Lichtenberg, F. (1999). Information Technology and its Impact on Productivity: Firm-Level Evidence from Government and Private Data Sources, Canadian Journal of Economics 32(2): 335-362.

Leung, S. F. and Yu, S. (1996). On the Choice between Sample Selection and Two-Part Models, Journal of Econometrics 72: 197-229.

Manasian, D. (2003). A Survey of the Internet Society, The Economist. January 25 th. 
Manning, W. G., Duan, N. and Rogers, W. H. (1987). Monte Carlo Evidence on the Choice between Sample Selection and Two-Parts Models, Journal of Econometrics 35: 59-82.

Nelson, R. R. and Winter, S. (1982). An Evolutionary Theory of Economic Change, Harvard University Press, Cambridge MA.

OECD (2001). The New Economy: Beyond the Hype, Final Report on the OECD Growth Project, OECD.

OECD (2002a). Education at a Glance - OECD Indicators 2002, Paris.

OECD (2002b). OECD Information Technology Outlook - ICTs and the Information Economy, Paris.

OECD/Eurostat (1997). Proposed Guidelines for Collecting and Interpreting Technological Innovation Data, Technical report, OECD/Eurostat.

Puhani, P. A. (2000). The Heckman Correction for Sample Selection and its Critique, Journal of Economic Surveys 14(1): 53-68.

Rendtel, U. (1992). On the Choice of a Selection-Model when Estimating Regression Models with Selectivity, DIW-Discussion Paper No. 53, German Institute for Economic Research, Berlin.

Schreyer, P. (2000). The Contribution of Information and Communication Technology to Output Growth: A Study of the G7 Countries, STI Working Paper 2000/2, OECD.

Spitz, A. (2003). IT Capital, Job Content, and Educational Attainment, ZEW Discussion Paper 03-04, Centre for European Economic Research. (ftp://ftp.zew.de/pub/zew-docs/dp/dp0304.pdf).

Zwick, T. (2002). Continuous Training and Firm Productivity in Germany, ZEW Discussion Paper No. 02-50, Centre for European Economic Research. 


\section{Appendix A: Sensitivity analysis of sample selec- tion}

Expenditures on investments and training are restricted to positive values. Moreover, they tend to be highly skewed and clustered around zero and to follow a lognormal (rather than a normal) distribution.52 Consequently, I employ the logs of the corresponding expenditures in the estimation equation. This specification, however, excludes observations with zero expenditures from the analysis. If the decision to whether to invest or not to invest at all is impacted by a different set of determinants, this may induce a selectivity bias in the analysis.

The problem of selectivity due to zeros in logarithmic specifications is well-known in the literature ${ }^{53}$ The probably most popular approach to correct for this selectivity in the microeconometric literature is the two-step procedure proposed by Heckman $(1976,1979)$ and its variants. This model estimates the selection hazard rate by a probit model and includes this rate as an additional explanatory in the OLS estimation of the equation of interest (outcome equation) for the subsample with non-zero observations. Alternatively, the so called 'two-part model' estimates the model of interest without any control for sample selection and corrects only the predicted outcome by the probability of the observation satisfying the selectivity criterion (which is obtained from a suited probit estimation) ${ }^{54}$ If one is mainly interested in the coefficients of the determinants and not so much in the predicted outcome, the two-parts model reduces to a simple subsample estimation (of non-zero observations). The main difference as against the selection model is that "[t]he two-part model maintains that the level of use, given any, is conditionally independent of the decision to use" (Leung and Yu, 1996, p. 202).

There has been an extensive discussion in the econometric literature - based both on theoretical properties and Monte-Carlo simulation — about which of the approaches is the more appropriate one. In a comprehensive evaluation of this literature, Puhani (2000) points to the need for finding appropriate exclusion restrictions (i.e. variables that are relevant in the selection equation but not for the outcome equation). Without imposing any exclusion restrictions, the distinction between the selection and the outcome effect is due only to the differing functional form of the linear outcome function and the non-linearity of the selection hazard rate. This may cause substantial problems of collinearity for small values of the hazard rate. 55 By contrast, a misspecified exclusion restriction may be very harmful to the performance of the selection model (Rendtel, 1992).

Applied to the specific context of this study, there are few variables that may

\footnotetext{
${ }^{52}$ This holds also for the expenditure variables employed in this study.

${ }^{53}$ See Manning, Duan and Rogers (1987), e.g.

${ }^{54}$ See Leung and $\mathrm{Yu}$ (1996) for a detailed comparison of the two alternative approaches.

${ }^{55}$ Similarly, a small variability among the regressors, a large error variance in the choice equation as well as high degrees of censoring may further intensify the problem of multicollinearity (Leung and $\mathrm{Yu}, 1996)$.
} 
Table 7: Investment expenditures in non-ICT, ICT and training with Heckman nonselection hazard

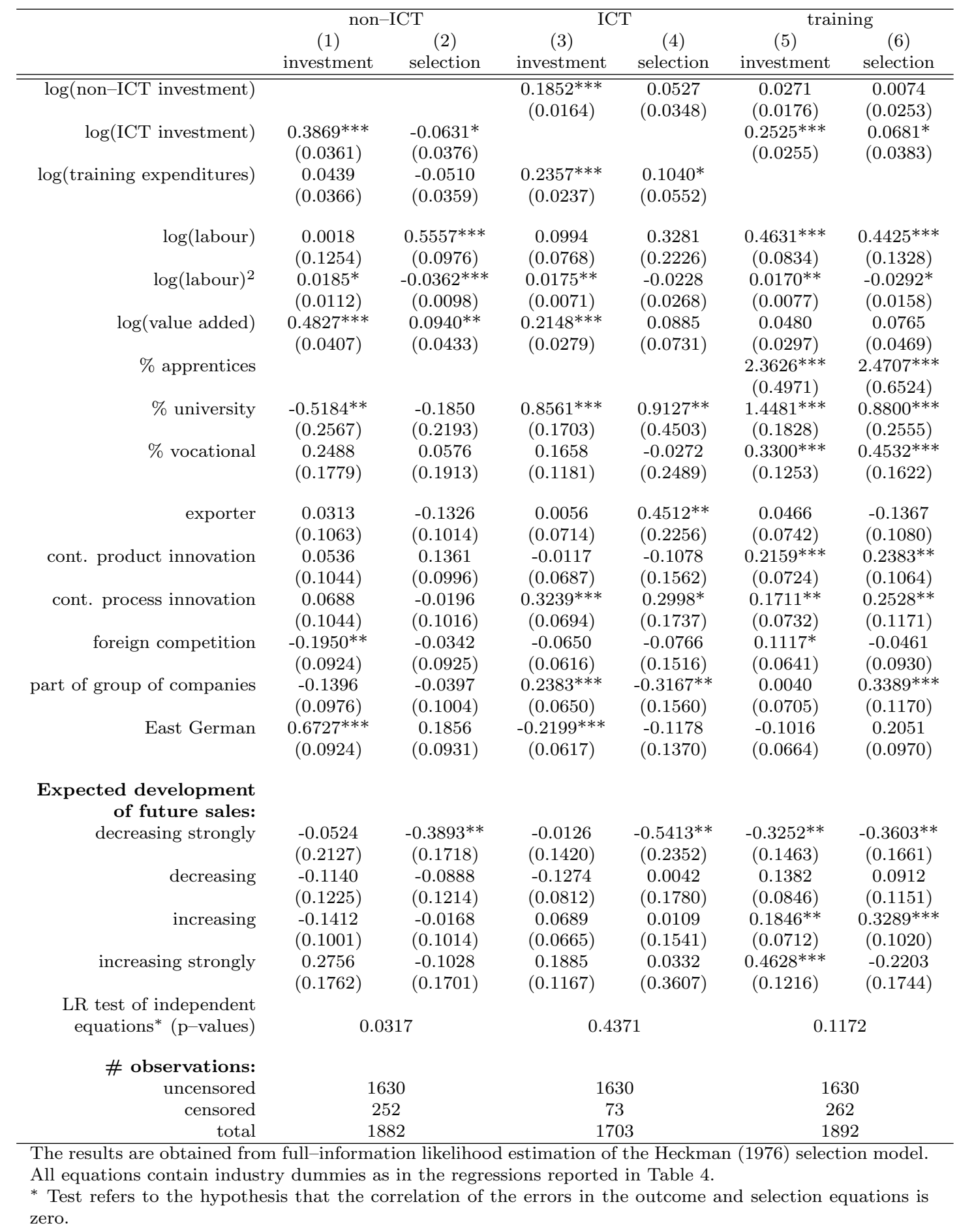

serve as candidates for exclusion restrictions. In order to explore the robustness of the results found in the main part, I investigate to what extent the qualitative results obtained for the uninstrumented investment demand (as in the first three 
columns of Table 4 may be biased due to selectivity. For this purpose, I rerun all three equations individually by applying a full-information maximum likelihood estimation of the Heckman selection model. Since there are no variables that might serve as exclusion restrictions, the selection equation and the output equation contain the same set of regressors 5 The comparison of the corresponding results for the demand equation reported in Table 7 show that the qualitative results (both in sign and significance of the main variables of interest) are the same as the findings obtained for the regressions that did not take selectivity into account. Moreover, the likelihood-ratio test of independence of the two equations 57 is rejected only in the case of non-ICT demand but not for the ICT and training equations. These explorations yield support for the conjecture that the results obtained from the subsample regressions do not suffer from any important selection biases.

\footnotetext{
${ }^{56}$ In an alternative specification, I employed expectations of diminishing sales as an exclusion restriction for the model. Given that gross investments cannot be negative, this approach is based on the hypothesis that falling sales will mainly increase the probability that the firm does not invest at all. The results of this alternative specification, however, are broadly the same as in the specification without any exclusion restriction.

${ }^{57}$ This test explores whether the correlation coefficient between the errors of the output and the selection equation is equal to zero.
} 


\section{Appendix B: Tables and Graphs}

Table 8: Decriptive statistics for regression samples

\begin{tabular}{|c|c|c|c|c|}
\hline \multirow[b]{2}{*}{ Variables* } & \multicolumn{2}{|c|}{$\begin{array}{l}\text { 1st sample:** } \\
\text { factor demand }\end{array}$} & \multicolumn{2}{|c|}{$\begin{array}{l}\text { 2nd sample:** } \\
\text { prod. and wage reg. }\end{array}$} \\
\hline & Mean & standard dev. & Mean & standard dev. \\
\hline $\log ($ non-ICT investment) & -0.9655 & 2.5324 & & \\
\hline $\log (\mathrm{ICT}$ investment $)$ & -2.4872 & 2.0198 & & \\
\hline $\log$ (training expenditures) & -3.1597 & 1.9194 & -3.3834 & 1.7134 \\
\hline $\log ($ non-ICT stock $)$ & 1.3978 & 2.5319 & 1.1878 & 2.6122 \\
\hline $\log (\mathrm{ICT}$ stock $)$ & -1.5848 & 2.0016 & -1.9802 & 1.7745 \\
\hline $\log$ (training stock) & -1.270 & 1.8796 & -1.3754 & 1.6173 \\
\hline $\log ($ labour $)$ & 4.1859 & 1.5904 & 4.0637 & 1.5588 \\
\hline $\log ($ value added $)$ & 2.4910 & 2.1373 & 1.8979 & 1.6193 \\
\hline$\%$ university & 0.1947 & 0.2527 & 0.2214 & 0.2789 \\
\hline$\%$ vocational & 0.6000 & 0.2870 & 0.5502 & 0.2944 \\
\hline$\%$ apprentices & 0.0461 & 0.0638 & & \\
\hline dummy variables: & & & & \\
\hline exporter & 0.2393 & 0.4267 & & \\
\hline cont. product innovation & 0.5264 & 0.4995 & & \\
\hline cont. process innovation & 0.4227 & 0.4941 & & \\
\hline foreign competition & 0.3656 & 0.4669 & & \\
\hline part of group of companies & 0.3466 & 0.4760 & & \\
\hline East German & 0.4135 & 0.4926 & 0.4715 & 0.4994 \\
\hline $\begin{array}{l}\text { Expected development } \\
\text { of future sales: }\end{array}$ & & & & \\
\hline decreasing strongly & 0.0429 & 0.2028 & & \\
\hline decreasing & 0.1755 & 0.3805 & & \\
\hline increasing & 0.4172 & 0.4932 & & \\
\hline increasing strongly & 0.0712 & 0.2571 & & \\
\hline \# obs. & & 1630 & & 1249 \\
\hline \# firms & & 1241 & & 393 \\
\hline
\end{tabular}


Table 9: Average of absolute annual percentage changes in composition of skills and capital

\begin{tabular}{rc} 
variable ratios & annual changes in \% points \\
\hline university/employees & 3.94 \\
vocational/employees & 9.47 \\
ICT stock/non-ICT stock & 7.24 \\
training stock/stock of tangibles & 9.77
\end{tabular}

The numbers report the mean of the absolute within changes of the corresponding shares in percentage points for the 2nd sample with panel data from 393 firms.

Table 10: Number of firms in samples and population by industries

\begin{tabular}{|c|c|c|c|c|c|c|}
\hline & & & & les & & population* \\
\hline & & & & & & \\
\hline industry & nace-digit & $\#$ & $\%$ & $\#$ & $\%$ & $\%$ \\
\hline wholesale trade & 51 & 155 & 12.5 & 50 & 12.7 & 10.4 \\
\hline retail trade & 50,52 & 149 & 12.0 & 54 & 13.7 & 30.8 \\
\hline transport and postal services & $60-63,64.1$ & 174 & 14.0 & 66 & 16.8 & 11.5 \\
\hline electr. processing and telecom & $72,62.2$ & 90 & 7.3 & 33 & 8.4 & 3.4 \\
\hline consultancies & $74.1,74.4$ & 95 & 7.7 & 40 & 10.2 & 11.8 \\
\hline technical services & $73,74.2,74.3$ & 144 & 11.6 & 60 & 15.3 & 10.5 \\
\hline banking and insurances & $65,66,67$ & 167 & 13.5 & - & - & 1.7 \\
\hline other business-rel. services & $70,7174,5-.8,90$ & 267 & 21.5 & 90 & 22.9 & 19.9 \\
\hline total & & 1241 & 100 & 393 & 100 & 100 \\
\hline
\end{tabular}

*German service firms with 5 and more employees in 1999.

\# denote number of firms, $\%$ percentages of total.

Source: German Statistical Office, ZEW and own calculations

** "1st" denotes sample used for the analysis of the interrelated factor demand,

"2nd" denotes sample used for the productivity and wage cost regressions. 
Graph A Histograms of the shares of ICT investments in total investment

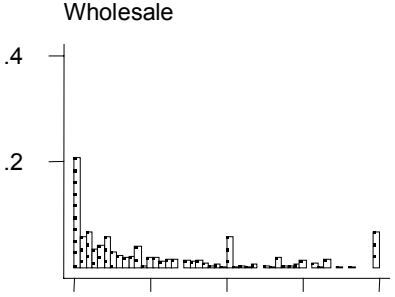

Other Business-rel. services

.4

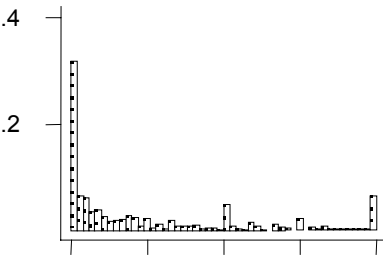

Technical Services

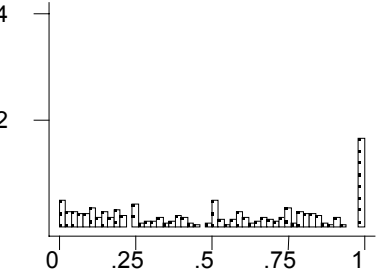

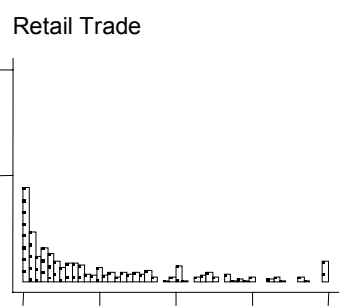

Electronic Processing and Teleco

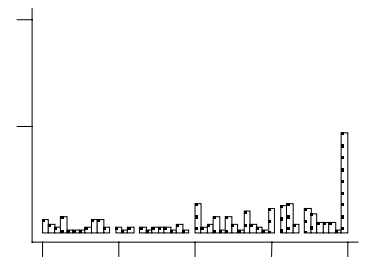

Banking and Insurances

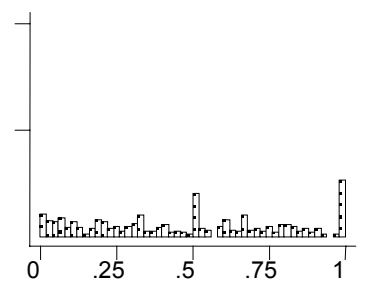

Postal and Transport

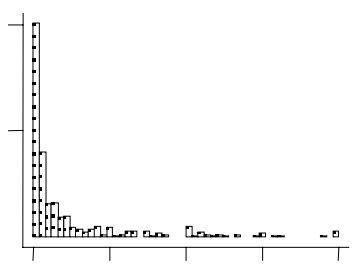

Consultancies

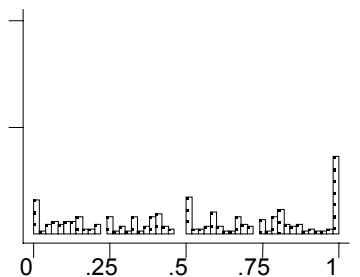

Observations are based on the time averages of nominal investments in tangible assets for an unbalanced panel of 4053 firms for the period 1994-98. 